\title{
Aerosols in the tropical and subtropical UT/LS: in-situ measurements of submicron particle abundance and volatility
}

\author{
S. Borrmann ${ }^{1,2}$, D. Kunkel ${ }^{1}$, R. Weigel ${ }^{2}$, A. Minikin ${ }^{3}$, T. Deshler ${ }^{4}$, J. C. Wilson ${ }^{5}$, J. Curtius ${ }^{6}$, C. M. Volk ${ }^{7}$, \\ C. D. Homan ${ }^{7, *}$, A. Ulanovsky ${ }^{8}$, F. Ravegnani ${ }^{9}$, S. Viciani ${ }^{10}$, G. N. Shur ${ }^{8}$, G. V. Belyaev ${ }^{11}$, K. S. Law $^{12}$, and F. Cairo ${ }^{9}$ \\ ${ }^{1}$ Max-Planck-Institute for Chemistry, Particle Chemistry Department, Germany \\ ${ }^{2}$ Institute for Atmospheric Physics, Johannes-Gutenberg-University, Mainz, Germany \\ ${ }^{3}$ Institut für Physik der Atmosphäre, DLR, Oberpfaffenhofen, Germany \\ ${ }^{4}$ Department of Atmospheric Science, University of Wyoming, Laramie, WY, USA \\ ${ }^{5}$ Department of Mechanical Engineering, Denver University, Denver, CO, USA \\ ${ }^{6}$ Institute for Atmospheric and Environmental Sciences, Goethe University of Frankfurt, Germany \\ ${ }^{7}$ Department of Physics, Wuppertal University, Wuppertal, Germany \\ ${ }^{8}$ Central Aerological Observatory, Dolgoprudny, Moscow Region, Russia \\ ${ }^{9}$ Institute of Atmospheric Science and Climate, ISAC-CNR, Rome, Italy \\ ${ }^{10}$ National Institute of Optics (INO), CNR, Florence, Italy \\ ${ }^{11}$ MDB-Myasishchev Design Bureau, Zhukovsky-5, Moscow Region, Russia \\ ${ }^{12}$ UPMC Univ. Paris 06, Université Versailles St-Quentin, CNRS/INSU, LATMOS-IPSL, Paris, France \\ *now at: KNMI, De Bilt, The Netherlands
}

Received: 16 October 2009 - Published in Atmos. Chem. Phys. Discuss.: 18 November 2009

Revised: 30 April 2010 - Accepted: 30 May 2010 - Published: 23 June 2010

\begin{abstract}
Processes occurring in the tropical upper troposphere (UT), the Tropical Transition Layer (TTL), and the lower stratosphere (LS) are of importance for the global climate, for stratospheric dynamics and air chemistry, and for their influence on the global distribution of water vapour, trace gases and aerosols. In this contribution we present aerosol and trace gas (in-situ) measurements from the tropical UT/LS over Southern Brazil, Northern Australia, and West Africa. The instruments were operated on board of the Russian high altitude research aircraft M-55 "Geophysica" and the DLR Falcon-20 during the campaigns TROCCINOX (Araçatuba, Brazil, February 2005), SCOUT-O3 (Darwin, Australia, December 2005), and SCOUT-AMMA (Ouagadougou, Burkina Faso, August 2006). The data cover submicron particle number densities and volatility from the COndensation PArticle counting System (COPAS), as well as relevant trace gases like $\mathrm{N}_{2} \mathrm{O}$, ozone, and $\mathrm{CO}$. We use these trace gas measurements to place the aerosol data into a
\end{abstract}

Correspondence to: S. Borrmann (stephan.borrmann@mpic.de) broader atmospheric context. Also a juxtaposition of the submicron particle data with previous measurements over Costa Rica and other tropical locations between 1999 and 2007 (NASA DC-8 and NASA WB-57F) is provided. The submicron particle number densities, as a function of altitude, were found to be remarkably constant in the tropical UT/LS altitude band for the two decades after 1987. Thus, a parameterisation suitable for models can be extracted from these measurements. Compared to the average levels in the period between 1987 and 2007 a slight increase of particle abundances was found for $2005 / 2006$ at altitudes with potential temperatures, $\Theta$, above $430 \mathrm{~K}$. The origins of this increase are unknown except for increases measured during SCOUTAMMA. Here the eruption of the Soufrière Hills volcano in the Caribbean caused elevated particle mixing ratios. The vertical profiles from Northern hemispheric mid-latitudes between 1999 and 2006 also are compact enough to derive a parameterisation. The tropical profiles all show a broad maximum of particle mixing ratios (between $\Theta \approx 340 \mathrm{~K}$ and $390 \mathrm{~K}$ ) which extends from below the TTL to above the thermal tropopause. Thus these particles are a "reservoir" for

Published by Copernicus Publications on behalf of the European Geosciences Union. 
vertical transport into the stratosphere. The ratio of nonvolatile particle number density to total particle number density was also measured by COPAS. The vertical profiles of this ratio have a maximum of $50 \%$ above $370 \mathrm{~K}$ over Australia and West Africa and a pronounced minimum directly below. Without detailed chemical composition measurements a reason for the increase of non-volatile particle fractions cannot yet be given. However, half of the particles from the tropical "reservoir" contain compounds other than sulphuric acid and water. Correlations of the measured aerosol mixing ratios with $\mathrm{N}_{2} \mathrm{O}$ and ozone exhibit compact relationships for the tropical data from SCOUT-AMMA, TROCCINOX, and SCOUT-O3. Correlations with $\mathrm{CO}$ are more scattered probably because of the connection to different pollution source regions. We provide additional data from the long distance transfer flights to the campaign sites in Brazil, Australia, and West-Africa. These were executed during a time window of 17 months within a period of relative volcanic quiescence. Thus the data represent a "snapshot picture" documenting the status of a significant part of the global UT/LS fine aerosol at low concentration levels 15 years after the last major (i.e., the 1991 Mount Pinatubo) eruption. The corresponding latitudinal distributions of the measured particle number densities are presented in this paper to provide data of the UT/LS background aerosol for modelling purposes.

\section{Introduction}

In the upper troposphere and lower stratosphere (UT/LS) aerosols influence the radiative budget and the actinic fluxes for photochemical reactions, serve as condensation nuclei for altocumulus and cirrus cloud formation (Krämer et al., 2009), and provide sites for heterogeneous chemical reactions (Borrmann et al., 1997).

Of particular importance for many of the aerosol and cloud related processes in the tropics is the so-called Tropical Transition Layer (TTL) within the UT/LS. It is defined as the altitude band between an upper "boundary level" somewhat above the thermal tropopause and the level of net zero radiative heating as lower "limiting surface" (Fueglistaler et al., 2009). This lower boundary often also is close to the level of neutral buoyancy where convection - with the exception of occasional overshooting - does not suffice to lift air parcels any higher. Based on measurements over Costa Rica and Australia, Park et al. (2007), proposed that the TTL may consist of two layers: The upper TTL being characterised by slow radiatively driven vertical ascent, and the lower TTL being influenced by convective outflow. In the lower TTL detrainment of air occurs which was lifted from as far below as the boundary layer and possibly processed by deep convective cumulonimbus clouds. In the recent review paper by Fueglistaler et al. (2009), a "synthesis definition" for the
TTL is given by specifying a lower TTL "boundary" level of $\Theta=355 \mathrm{~K}$ potential temperature (equivalent to $150 \mathrm{hPa}$ ambient pressure, or $14 \mathrm{~km}$ of altitude) and a TTL top level with the corresponding values of $425 \mathrm{~K}, 70 \mathrm{hPa}$, and $18.5 \mathrm{~km}$. Since the tropical tropopause typically is located at potential temperatures $\Theta \approx 380 \mathrm{~K}$, or roughly 16 to $18 \mathrm{~km}$ altitude, it is situated within the TTL. The latitudinal boundaries of the TTL are given by the subtropical jets and thus the TTL can be considered as sub-volume of the UT/LS region, and as interface between the free troposphere and the stratospheric overworld. The intermediate dynamical and radiative characteristics of the TTL with several weeks of air residence times (Plöger et al., 2010; Krüger et al., 2009) allow microphysical and chemical processes to greatly affect tropospheric air entering the stratosphere.

The aerosols in the tropical upper troposphere and TTL most likely contribute significantly to the particles of the global stratospheric Junge layer (Brock et al., 1995), and may influence the transport of water vapour into the stratosphere (Corti et al., 2008; Gettelman et al., 2009; Luo et al., 2003a). Water vapour contained in the upwelling air is removed in significant amounts within the TTL through freeze drying in thin visible, subvisible and opaque cirrus. This is the basis of the stratospheric water vapour tape recorder phenomenon (Mote et al., 1996; Randel et al., 2001; Randel et al., 2004). The formation of cirrus and subvisible cirrus is dependent on the properties of the aerosol (Thomas et al., 2002; Peter et al., 2003; Luo et al., 2003b; Davis et al., 2010) although the exact mechanisms leading to nucleation and cloud formation in the TTL still are unknown (Froyd et al., 2009). From in-situ cloud and submicron aerosol particle data, de Reus et al. (2009), showed that in the tropical upper troposphere typically one in 3000 aerosol particles can be activated to form an ice particle with occasional values as high as one in 300 and as low as one in 30000 . More recently Froyd et al. (2010), presented air-borne mass spectrometric composition measurements of ice residues from tropical cirrus and subvisible cirrus clouds. They concluded that most ice residuals consisted of internal mixtures of neutralised sulphate and some organics (similar to liquid sulphuric acid droplets) and that mineral dust or other heterogeneous nuclei do not play a role in cirrus formation. How much this can be generalised is an open question as other studies indicate the importance of metals (Cziczo et al., 2009, and references therein), mineral dust (DeMott et al., 2003; Zimmermann et al., 2008; Kulkarni and Dobbie, 2010), and organics (Murray et al., 2010).

According to current belief, the major source for aerosol particles in the lower stratosphere is gas-to-particle conversion of precursor gases like OCS, $\mathrm{CS}_{2}$, and $\mathrm{SO}_{2}$ ultimately forming binary sulphuric acid/water droplets (Thomason and Peter, 2006; Wilson et al., 2008; see especially Sipilä et al., 2010). Brock et al. (1995) suggested that fine and ultrafine particles present or formed in the tropical upper troposphere can be transported into the stratosphere. Organic components 
also may be involved (Ekman et al., 2008; Froyd et al., 2009) in the homogeneous new particle formation. This is supported by mass-spectrometric in-situ measurements from Murphy et al. (1998), who found that "organic material was almost always present" in the UT/LS particles. In addition, the UT/LS particle mass spectra from Murphy et al. (1998), indicated the presence of metals like iron, magnesium, and even mercury. Also Nielsen et al. (2007) detected solid particles of unknown origin in the tropical lower stratosphere. A study based on numerical simulation of observed in-situ data indicates that ion induced nucleation in the UT/LS facilitates gas to particle conversion for the $\mathrm{H}_{2} \mathrm{SO}_{4} / \mathrm{H}_{2} \mathrm{O}$ system (Lee at al., 2003; Lovejoy et al., 2004) and thus may be an important source of UT/LS aerosols. According to Lee et al. (2004), inside tropical upper tropospheric cirrus clouds new particle nucleation events can occur. However, the significance of this source for the global UT/LS aerosol and the underlying mechanisms are still unknown. Based on recent laser ablation mass spectrometric in-situ measurements in the TTL over Costa Rica, Froyd et al. (2009) showed that significant numbers of particles with sizes above $500 \mathrm{~nm}$ contain oxidised organic compounds. They also conclude that the chemical composition of these larger particles in the tropical TTL depends on tropical dynamics, regional sources (implying boundary layer processes as well) and the occurrence of overshooting cumulonimbus clouds. Furthermore, evidence has been presented by Popp et al. (2006), Hervig and McHugh (2002), suggesting (like Hamill and Fiocco based on theoretical considerations already in 1988) that nitric acid trihydrate (NAT) particles are present in the tropical transition layer. Based on numerical simulations of the microphysics and thermodynamics and on global modelling, it was hypothesised that these may even form a "tropical tropopause NAT belt" (Voigt et al., 2008) although robust evidence for this is still lacking.

A comprehensive, recent overview of the mechanisms underlying stratospheric aerosol microphysics and chemistry, as well as observations, volcanic influence, climatology, trends, and modelling of stratospheric aerosols including references to the relevant literature were presented by Thomason and Peter (2006) in the WRCP SPARC Assessment Report No. 4 and in Chapter 3 of WMO (1999).

Summarising, the aerosols in the upper troposphere and lower stratosphere seem to originate (1) from gas-to-particle conversion processes, possibly involving organic substances, and possibly influenced by ions induced from cosmic rays, as well as (2) from lifting processes (like deep, overshooting convection) which transport gases and particulate materials from the boundary layer to the UT/LS. (3) Cirrus clouds also may play a role as sources for submicron particles. (4) Aerosols present in the tropical UT may form a reservoir of particles amenable for transport into the lower stratosphere. (5) With respect to the chemical composition of the aerosol particles, sulphuric acid-water solutions are assumed to be the major components in the lower stratosphere while more complex composition including organic materials may be found in the TTL. Also, metals, possibly soot and biomass burning residues can play a role for the chemical composition.

It is quite clear that the mechanisms controlling particle production, ageing and composition, as well as the global spatial and temporal distribution of the sources are to a large extent unknown or at least un-quantified for the tropical UT/LS and the TTL. Obviously, this short (and incomplete) survey of the recently gained knowledge demonstrates that an increasingly complex picture evolves with respect to the microphysics and dynamics of the tropical UT/LS and in particular the TTL aerosols. This complexity is also reflected in CCM and CTM (e.g., Palazzi et al., 2009; Plöger et al., 2010) and mesoscale models (e.g., BOLAM; Fierli et al., 2009) which include TTL properties.

The aims of this study are: (1) To provide in-situ data for submicron particle number densities at altitudes above $14 \mathrm{~km}$ during the time of relative volcanic quiescence (from January 2005 until August 2006, although at the end of this period a small eruption played a role). The data include, in addition to the local mission flights, transfer flights of the Russian M-55 high altitude research aircraft "Geophysica" and the DLR Falcon-20 from Europe to Brazil (TROCCINOX, 2005), to Northern Australia (2005), and to West Africa (SCOUT-AMMA, 2006). (2) To relate these measurements to 1999-2007 data from other tropical locations like Costa Rica and to earlier data from Hawaii. (3) To show vertical profile in-situ data of submicron particle number concentrations up to $20 \mathrm{~km}$ altitude from Brazil, West Africa and Northern Australia, and place these into a broader atmospheric context (4) To present and discuss results from measurements of non-volatile residues.

The main instruments used to obtain the data are specialised condensation particle counters (CPCs). For the M55 "Geophysica" this is the COPAS (COndensation PArticle counter System; see Weigel et al., 2009) while an NMASS instrument was operated by the University of Denver on the NASA DC-8 and NASA WB-57F. Similar instruments were implemented on the German DLR Falcon-20 and a balloon borne CPC was utilised by the University of Wyoming. In addition measurements of gaseous species like $\mathrm{N}_{2} \mathrm{O}$, ozone and CO from the M-55 "Geophysica" flights are presented in connection with the aerosol data.

\section{Atmospheric context of the TROCCINOX, SCOUT- O3, and SCOUT-AMMA field campaigns}

The measurements presented here originate from local flights of the M-55 "Geophysica" and the German DLR Falcon-20 research aircraft during the campaigns: TROCCINOX (from Araçatuba, Brazil; Schumann, 2005), SCOUT-O3 (based in Darwin, Australia; Vaughan et al., 2008; Brunner et al., 2009), and SCOUT-AMMA (from Ouagadougou, Burkina 


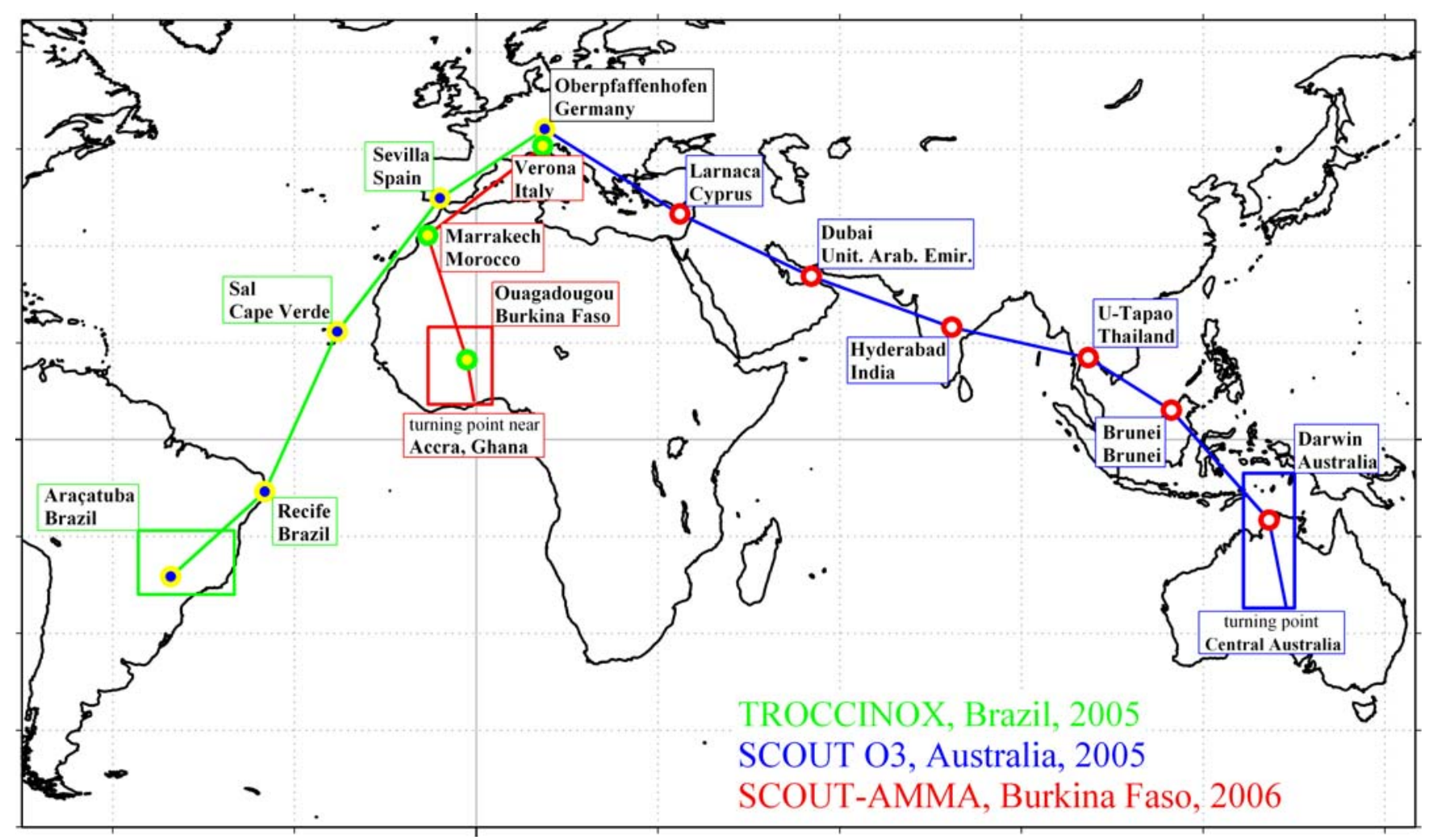

Fig. 1. Routes of the transfer flights for the M-55 "Geophysica" with intermediate landings between January 2005 and August 2006. The boxes indicate the areas where local research flights were carried out.

Table 1. Locations and times of the tropical campaigns TROCCINOX, SCOUT-O3, and SCOUT-AMMA with the Russian M-55 "Geophysica" and the German DLR Falcon-20 research aircraft.

\begin{tabular}{|c|c|c|c|}
\hline & TROCCINOX & SCOUT-O3 & SCOUT-AMMA \\
\hline Time period & Jan-Mar 2005 & Nov-Dec 2005 & Jul-Aug 2006 \\
\hline Location of local & Araçatuba & Darwin & Ouagadougou \\
\hline mission flights & Brazil & Australia & Burkina Faso \\
\hline at latitude and lon- & $21^{\circ} 8^{\prime} 37^{\prime \prime} \mathrm{S}$ lat. & $12^{\circ} 28^{\prime} 0^{\prime \prime} \mathrm{S}$ lat., & $12^{\circ} 22^{\prime} 13^{\prime \prime} \mathrm{N}$ lat. \\
\hline gitude & $50^{\circ} 25^{\prime} 34^{\prime \prime} \mathrm{W}$ long. & $130^{\circ} 50^{\prime} 1^{\prime \prime} \mathrm{E}$ long. & $1^{\circ} 31^{\prime} 29^{\prime \prime} \mathrm{W}$ long. \\
\hline Transfer flights & Oberpfaffenhofen & Oberpfaffenhofen & Verona \\
\hline originating from & Germany & Germany & Italy \\
\hline at latitude and & $48^{\circ} 5^{\prime} 0^{\prime \prime} \mathrm{N}$ lat. & $48^{\circ} 5^{\prime} 0^{\prime \prime} \mathrm{N}$ lat. & $45^{\circ} 23^{\prime} 45^{\prime \prime} \mathrm{N}$ lat. \\
\hline longitude & $11^{\circ} 17^{\prime} 0^{\prime \prime} \mathrm{E}$ long. & $11^{\circ} 17^{\prime} 0^{\prime \prime} \mathrm{E}$ long. & $10^{\circ} 53^{\prime} 19^{\prime \prime} \mathrm{E}$ long. \\
\hline Transfer flight & 20 Jan 2005 & 4 Nov 2005 & $31 \mathrm{Jul} 2006$ \\
\hline time period to cam- & until & until & until \\
\hline paign site & 27 Jan 2005 & 12 Nov 2005 & 1 Aug 2006 \\
\hline Return transfer & 24 Feb 2005 & 9 Dec 2005 & 16 Aug 2006 \\
\hline flight period & until & until & until \\
\hline & 2 Mar 2005 & 17 Dec 2005 & 17 Aug 2006 \\
\hline Campaign website & $\begin{array}{l}\text { http://www.pa.op.dlr.de/ } \\
\text { troccinox/ }\end{array}$ & $\begin{array}{l}\text { http://www.ozone-sec.ch.cam. } \\
\text { ac.uk/scout_o3/field_campaigns/ } \\
\text { Darwin/ }\end{array}$ & http://amma.igf.fuw.edu.pl \\
\hline $\begin{array}{l}\text { Reference for cam- } \\
\text { paign overview }\end{array}$ & Schumann (2005) & $\begin{array}{l}\text { Vaughan et al. (2008), } \\
\text { Brunner et al. (2009) }\end{array}$ & Cairo et al. (2010a) \\
\hline
\end{tabular}


Faso; Cairo et al., 2010a). Also data are shown from the transfer flights to the various campaign locations. The flight routes of these transfers are shown together with the intermediate stops in Fig. 1. Table 1 provides relevant details of the campaigns, the transfers, as well as websites for the participating research aircraft, their instrumentation, and flight patterns. In the time frame of the M-55 "Geophysica" transfer flights to Brazil and to Australia the DLR Falcon-20 also travelled at lower altitudes to these campaign locations performing measurements underway.

\subsection{Atmospheric background in 2005 and 2006}

The following paragraphs briefly describe - mostly from a trace gas measurement perspective - the broader atmospheric situation during which the campaigns were performed.

Quasi biennial oscillation: According to the analysed data from the Singapore station (as presented by the Institute for Meteorology, Freie Universität Berlin), the QBO (marked by the $10 \mathrm{~m} / \mathrm{s}$ isotachs) was in its westerly phase between 80 to $30 \mathrm{hPa}$ in January 2005 and between 80 and $70 \mathrm{hPa}$ still in September 2005. Afterwards the easterly phase was fully established throughout the stratosphere. The following downward propagating westerly phase passed the $30 \mathrm{hPa}$ level in February 2006 and reached flight altitudes in May 2006. Thus TROCCINOX took place in the westerly phase, SCOUT-O3 in the easterly, and SCOUT-AMMA again in the beginning westerly QBO phase (Cairo et al., 2010a; Brunner et al., 2009).

Boundary layer influence through convective outflow: SCOUT-AMMA was performed during the West African monsoon wet season. In order to characterize the TTL over West Africa Homan et al. (2010), analysed $\mathrm{CO}, \mathrm{CO}_{2}$, and other trace gas data. From the $\mathrm{CO}_{2}$ measurements they conclude that convective outflow significantly influenced the composition of the TTL between the $350 \mathrm{~K}$ and $370 \mathrm{~K}$ potential temperature levels by importing boundary layer air. At the same time the ozone data indicate the presence of more aged air. Law et al. (2010), analysed air mass origins in the TTL during August 2006 using domain filling trajectories over West Africa. Whilst most air masses were already residing in the TTL during the 10 days prior to the measurements, up to $39 \%$ of the air masses in the mid-TTL below $370 \mathrm{~K}$ were "perturbed" by injection of lower tropospheric air from Asia, India, and oceanic regions (Law et al., 2010). Fierli et al. (2010), used a regional mesoscale model together with the M-55 "Geophysica" observations of water vapour, ozone, $\mathrm{CO}_{2}$, and aerosol to demonstrate that signatures of the detrainment from deep convection of mesoscale convective systems can be found as high as $17 \mathrm{~km}$, and possibly higher in some cases. Furthermore, the vertical ozone profiles seem to indicate (Homan et al., 2010) that - in comparison with West Africa in August 2006 - the TTL over Darwin in De- cember 2005 was much more influenced by uplift from the regional boundary layer.

Cross hemispheric transport: Real et al. (2010) used BOLAM mesoscale model calculations (Fierli et al., 2010) in conjunction with trace gas measurements to confirm the presence of biomass burning plume remnants from central African fires in the upper troposphere. These were sampled during the M-55 "Geophysica" flight on 13 August 2006 with corresponding signatures in $\mathrm{CO}, \mathrm{CO}_{2}, \mathrm{NO}, \mathrm{NOy}$, and submicron aerosols. According to their study the pollutants remained over central Africa for 9 to 12 days before being lifted to the measurement altitude near Accra at $350 \mathrm{~K}$ to $360 \mathrm{~K}$ potential temperature altitudes. Thus interhemispheric transport may contribute to the composition of the TTL over West Africa.

Overshooting convection: Also from the analyses of two flights by Homan et al. (2010), it was concluded that overshooting convection did not have a major influence on the TTL composition for West Africa, while the in-situ measurements from Northern Australia, and also from Brazil provided direct evidence for this process (de Reus et al., 2009; Corti et al., 2008). Fierli (unpublished) and Khaykin et al. (2009), do show evidence for overshooting over West Africa. As a result evaporation of the ice particles lead to hydration within the TTL and lower tropical stratosphere (Corti et al., 2008) during TROCCINOX and SCOUT-O3.This is in reasonable agreement with the analysis of Law et al. (2010), although they found an influence from lower stratospheric air in the mid and upper TTL during the SCOUT-AMMA campaign period.

Isentropic mixing of extratropical stratospheric air and cross subtropical tropopause transport: Based on the in-situ measurements of $\mathrm{N}_{2} \mathrm{O}$ Homan et al. (2010), estimated the contribution of aged extratropical stratospheric air within the TTL over West Africa to be zero at levels up to $370 \mathrm{~K}$ and to be smaller than $20 \%$ at higher altitudes $(\approx 390 \mathrm{~K})$.

\subsection{Instrumentation for submicron particle and trace gas measurements}

The aerosol number concentration of ambient aerosol particles with size diameters between $6 \mathrm{~nm}$ and roughly $1 \mu \mathrm{m}$ was measured using two independent COndensation PArticle counter Systems (COPAS, Weigel et al., 2009), each having two channels. Three of the four channels sample the ambient aerosol with cut-off diameters (in terms of $50 \%$ detection efficiency) of 6,10 and $14 \mathrm{~nm}$, respectively. Because of the inlet design the upper size limit for the sampled particles is roughly $1 \mu \mathrm{m}$. The total aerosol number concentration in $\mathrm{cm}^{-3}$ for particles with diameters larger than 6,10 and $14 \mathrm{~nm}$ is denoted as $N_{6}, N_{10}$ and $N_{14}$ throughout this paper, while the particle mixing ratios (in number of particles per milligram of air) are given in lower case as $n_{6}, n_{10}, n_{14}$, or $n$. The fourth channel heats the sampled air containing the ambient aerosol particles to 


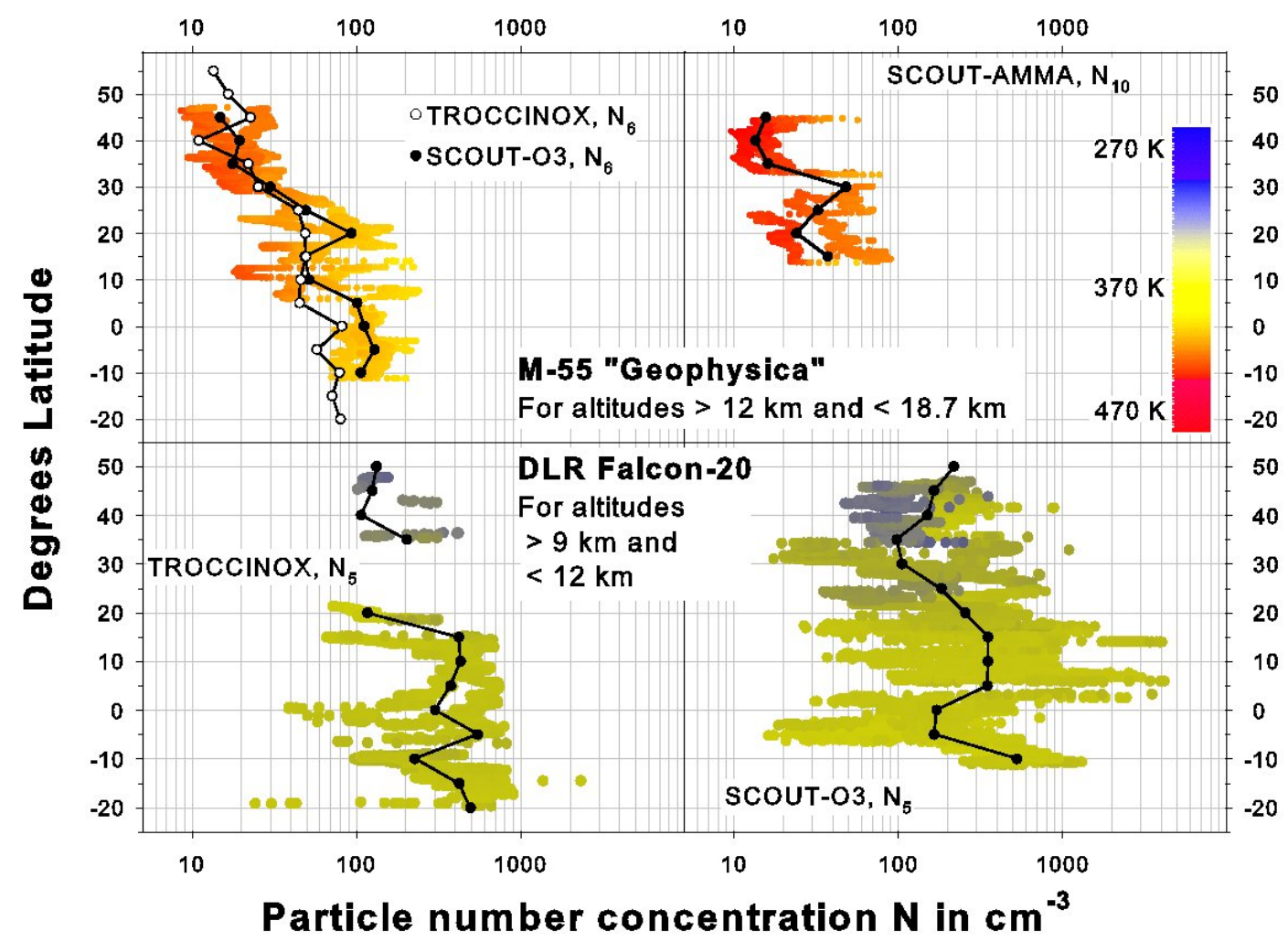

Fig. 2. Number densities and variability of submicron particles $N_{5}, N_{6}, N_{10}$ (i.e. with size diameters larger than $5 \mathrm{~nm}, 6 \mathrm{~nm}, 10 \mathrm{~nm}$, and smaller than $\approx 1 \mu \mathrm{m}$ ) as function of geographical latitude and altitude (in potential temperature) from the transfer flights. In all panels the filled dots and open circles associated with the black lines represent medians of five degree latitude bins and the coloured data points are $15 \mathrm{~s}$ flight time averages. Upper left panel: The line with the open circles includes flights between Germany and Brazil (20 to 27 January 2005 ; return: 24 February until 2 March 2005). The filled symbols refer to the transfer to Australia (4 until 12 November 2005) and back (9 until 17 December 2005). Upper right panel: Concentrations $\left(N_{10}\right)$ of the transfers from Europe to Burkina Faso (31 July and 1 August 2006) and back (16 and 17 August 2006). Lower panels: Latitudinal profiles of $N_{5}$ in the 9 to $12 \mathrm{~km}$ altitude band between Europe and Brazil (left) and between Europe and Australia (right).

$250^{\circ} \mathrm{C}$ (for a flow rate dependent duration between 3 and $6 \mathrm{~s})$ prior to the detection of the grown droplets. This way volatile ambient particles completely evaporate and only particles containing non-volatile residues larger than $10 \mathrm{~nm}$ are counted as number density $N_{10 \mathrm{nv}}\left(\mathrm{cm}^{-3}\right)$ or mixing ratio $n_{10 \mathrm{nv}}\left(\mathrm{mg}^{-1}\right)$. For stratospheric measurements this implies that binary solution droplets of sulphuric acid and water or ternary $\mathrm{H}_{2} \mathrm{SO}_{4} / \mathrm{H}_{2} \mathrm{O} / \mathrm{HNO}_{3}$ droplets evaporate resulting in zero counts of this channel. Only if, for example, particles of meteoric origin are contained inside these growing droplets their metallic or mineral core will not evaporate and the residual particles are detected as non-zero counts (see e.g., Curtius et al., 2005).

From the $1 \mathrm{~Hz}$ data delivered by COPAS typically $15 \mathrm{~s} \mathrm{av-}$ erages are calculated and displayed as running means in the figures below. The counting statistics are such that the sensor detects around 100 counts per second for ambient concentrations as low as 20 particles per $\mathrm{cm}^{3}$. Only at atmospheric particle concentrations as small as $2 \mathrm{~cm}^{-3}$ the count rate of the heated channel can drop to values as low as 30 per $15 \mathrm{~s}$.
In such (rare) circumstances fluctuations in the data may be due to counting statistics. At the cruise speed of the M-55 "Geophysica" (near $200 \mathrm{~m} \mathrm{~s}^{-1}$ ) these $15 \mathrm{~s}$ flight-time averages correspond to $3 \mathrm{~km}$ horizontal resolution along the flight path and for the typical ascent rate of $10 \mathrm{~m} \mathrm{~s}^{-1}$ a vertical resolution of $150 \mathrm{~m}$ results for the vertical profiles. The data of this paper represent the aged aerosol fraction because either no "new particle formation" events occurred during the flights or such data were removed. (Usually such "nucleation events" are associated with particle number densities $N_{6}$ being much larger than $N_{14}$ (Curtius et al., 2005; Heintzenberg et al., 2003).) A full experimental characterisation of COPAS with laboratory and aircraft borne experiments has been performed by Weigel et al. (2009).

Also on board of the M-55 "Geophysica" a Multiwavelength Aerosol Scatterometer (MAS; Cairo et al., 2004, 2010b; Buontempo et al., 2006) was operated, which is a backscatter sonde for in-situ measurements of optical air and aerosol parameters. The MAS measures volume backscatter ratio and depolarization ratio of the air in the vicinity of 
the aircraft at $532 \mathrm{~nm}$ and $1064 \mathrm{~nm}$ with a time resolution of $5 \mathrm{~s}$. For the backscatter ratio the measurement precision is $5 \%$ and the accuracy 0.05 . Its data can be used for the detection of cloud and aerosol particle ensembles and based on the polarization measurements, shape, and hence phase, of the optically active particles (i.e. those with size diameters larger than approximately $0.2 \mu \mathrm{m}$ ) can be discerned.

Nitrous oxide was measured on the M-55 "Geophysica" with $90 \mathrm{~s}$ time resolution by means of the High Altitude Gas Analyzer (HAGAR; Volk et al., 2000; Homan et al., 2010) which is a two-channel in-situ gas chromatograph. The precision and accuracy of the $\mathrm{N}_{2} \mathrm{O}$ measurements is better than $1.5 \%$. Carbon monoxide measurements were provided with $0.25 \mathrm{~Hz}$ sampling rate, a lower detection limit of a few ppbv, $1 \%$ precision, and 6-9\% accuracy by the COLD (Cryogenically Operated Laser Diode; Viciani et al., 2008) instrument. The Fast OZone ANalyzer (FOZAN; Yushkov et al., 1999; Ulanovsky et al., 2001) delivered ozone mixing ratios at a rate of $1 \mathrm{~Hz}$ with an accuracy of $10 \%$. The ambient temperature, was measured using a Thermo Dynamic Complex (TDC) probe with an accuracy of $0.5 \mathrm{~K}$ (Shur et al., 2007), while other relevant parameters as position and true air speed have been adopted from the onboard navigational system UCSE (Unit for Connection with the Scientific Equipment; Sokolov and Lepuchov, 1998).

Measurements of particle concentrations (here $N_{7}, N_{10}$ and $N_{5}$ ) also were performed on board of the DLR Falcon20 within the 9 to $12 \mathrm{~km}$ altitude band deploying a set of on board CPCs (Weinzierl et al., 2009; Minikin et al., 2003). Other data for this paper originate from balloon-borne in-situ measurements by means of a condensation particle counter (Rosen and Hofmann, 1977) during the SCOUT-AMMA campaign (2006) from Niamey, Niger, Africa. The particle measurements from the DC-8 and WB-57F (both NASA operated) were performed between 1999 and 2007 adopting a CPC of type NMASS from the University of Denver (Wilson et al., 1983; Brock et al., 2000). The Russian M-55 “Geophysica" and the NASA WB-57F are high altitude research aircraft capable of reaching $21 \mathrm{~km}$ and $16 \mathrm{~km}$, respectively, while the NASA DC- 8 and DLR Falcon 20 have a ceiling near $12 \mathrm{~km}$, and the balloons ascend to $\approx 30 \mathrm{~km}$. These platforms provided access to the tropical middle and upper troposphere, the lower stratosphere, and the TTL.

\section{Results and discussion}

\subsection{Background concentrations of submicron particles in the UT/LS}

The latitudinal distribution of the measured particle number concentrations $N_{5}, N_{6}, N_{10}$ from the transfer flights (see Fig. 1, Table 1) is shown in Fig. 2. The upper panels cover altitudes between $12 \mathrm{~km}(\Theta \approx 350 \mathrm{~K})$ and $18.7 \mathrm{~km}(\Theta \approx 460)$, and the lower panels correspond to potential temperatures

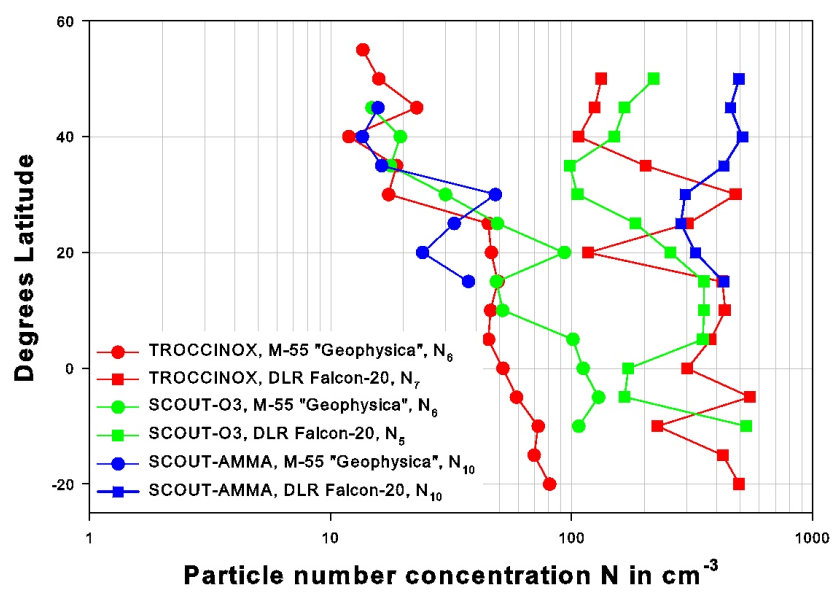

Fig. 3. Summary of the submicron particle concentration latitude profile data of Fig. 2 from the transfers of the DLR Falcon-20 and the M-55 "Geophysica" between Europe and Brazil, Australia, West Africa in 2005 and 2006.

from $315 \mathrm{~K}$ to $355 \mathrm{~K}$ for the altitude range from $9 \mathrm{~km}$ to $12 \mathrm{~km}$. Figure 3 shows the medians of this data, including additional DLR Falcon-20 measurements from the transfers to West Africa which are not shown in Fig. 2.

From the data at potential temperature levels above $367 \mathrm{~K}$, and slightly above the tropopause, an increase in particle number densities from values near $20 \mathrm{~cm}^{-3}$ at higher latitudes to values around $100 \mathrm{~cm}^{-3}$ can be seen in Figs. 2 and 3 for the transfer routes. The increase towards the tropics originates from the fact that the M-55 "Geophysica" was mostly flying at constant cruising altitudes (and always above the tropopause) which implies that in the northern latitudes stratospheric air was sampled and at lower latitudes air masses closer to the tropopause were encountered. Although in Fig. 3 there are small differences between the M55 "Geophysica" measurements during these transfers, overall the values and their latitudinal changes are remarkably close. The number concentrations of 10 to 50 particles per $\mathrm{cm}^{3}$ from the M-55 "Geophysica" flight across the Saharan desert in Fig. 3 fit well into the range of concentrations found at the same latitudes during the other flights. Thus for the times between January 2005 and July 2006 the measured number densities of small particles were fairly homogeneous along the different latitude bands. At lower altitudes within the $315 \mathrm{~K}$ to $355 \mathrm{~K}$ levels the DLR Falcon-20 data show values between 100 and 500 particles per $\mathrm{cm}^{3}$. From six CARIBIC flights across Africa in the year 2000 Heintzenberg et al. (2003) reported values for $N_{18}$, which were up to factor of five higher than what we measured for $N_{14}$ during the SCOUT-AMMA transfers. Since the flight altitudes of the DLR Falcon-20 and the CARIBIC commercial airliners were well within the tropical mid to upper troposphere, it is not surprising that the number densities differ and that the variability - as seen in the lower panels of Fig. 2 - is much larger than above the tropopause. 


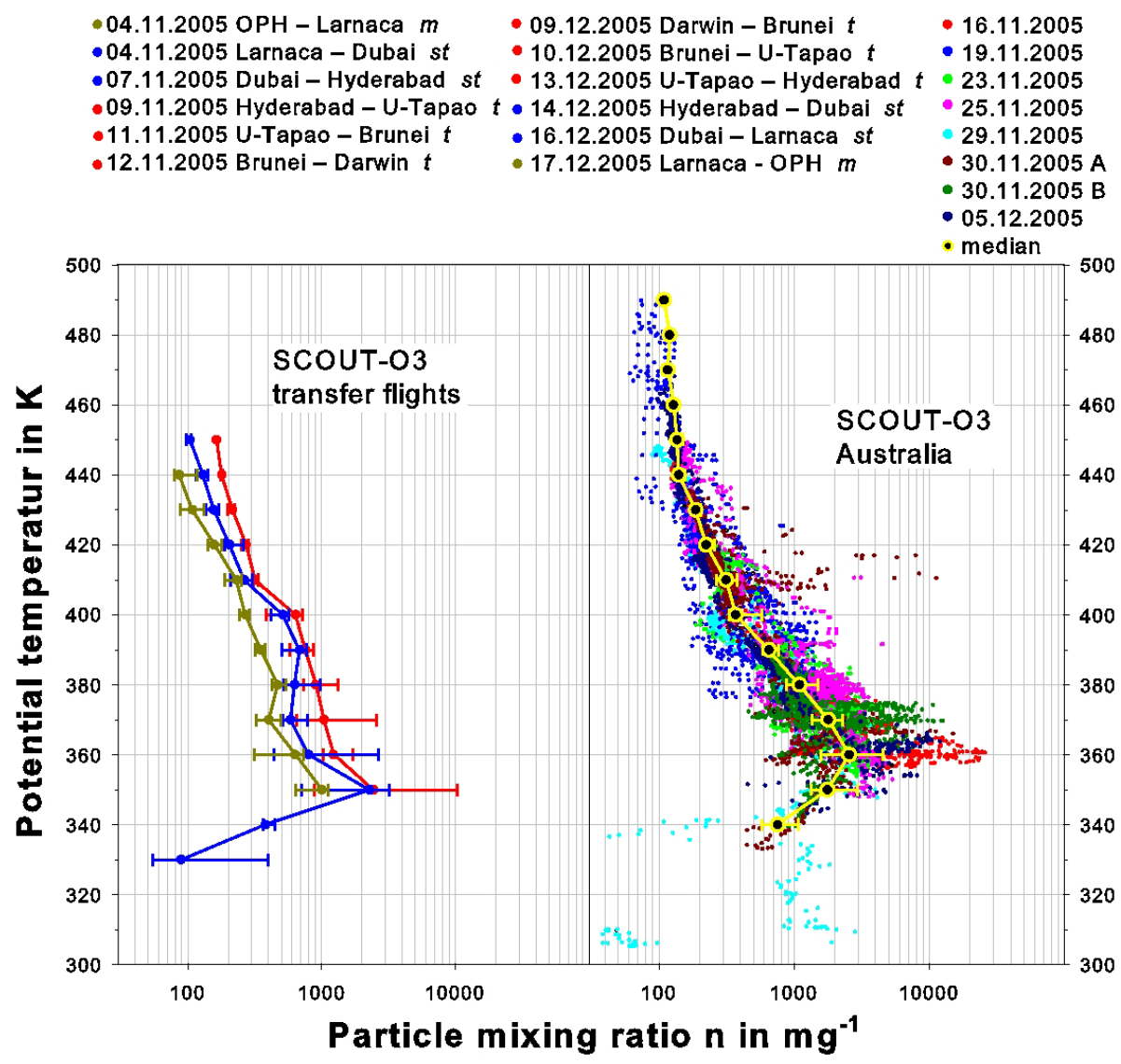

Fig. 4. Vertical profiles of COPAS particle mixing ratios as function of potential temperature (in K) for the transfer to/from Darwin and the local flights in Australia. The symbols are medians of $10 \mathrm{~K}$ bins and the bars denote $25 \%$ and $75 \%$ percentiles. Left panel: Vertical $n_{10}$ profile measurements during the intermediate descents and ascents from the transfer flight airports between Oberpfaffenhofen ("OPH", Germany) and Darwin (Australia). The denominations (and colours) refer to the geographical locations of these airports with "m" (dark green), "st" (blue), and "t" (red) standing for "mid-latitude", "sub-tropical", and "tropical". Similarly, the mid-latitude and sub-tropical data are comprehended in the blue and green curves. Right panel: Vertical profiles of $n_{10}$ obtained over Darwin. Here the colour code refers to the flight dates on the right side of the legend and the small points represent $15 \mathrm{~s}$ averages. The potential temperature of the cold point tropopause was near $375 \mathrm{~K}$.

\subsection{Vertical profiles of submicron particle mixing ratios in the tropical UT/LS between January 2005 and August 2006}

A subset of the $n_{6}, n_{10}, n_{14}, n_{10 \mathrm{nv}}$ vertical profiles obtained from the transfers to and from Darwin and the local flights from Darwin and Ouagadougou is shown in Figs. 4 and 5.

The left panel in Fig. 4 contains the COPAS vertical profile measurements from the landings and take-offs for the intermediate stops between Germany and Australia. The data are classified into tropical, sub-tropical, and mid-latitude profiles. For this placement of the respective airport locations the updated "Köppen-Geiger climate classification" was adopted (Kottek et al., 2006). Evidently, the particle mixing ratios over the entire altitude range increase towards the tropics (left panel). The right panel contains the data from the individual local flights over Darwin showing a distinct maximum between $360 \mathrm{~K}$ and $380 \mathrm{~K}$. (Note: According to the flight trajectories the values above 8000 particles per $\mathrm{mg}$ on 16 November 2005 at $360 \mathrm{~K}$ may have been caused by the M-55 "Geophysica" crossing its own contrail; Weigel et al., 2009). Figure 5 contains the local profiles from Ouagadougou in West Africa. Here the right (green) ensemble of points also indicates a strong increase of particle mixing ratios (like in the right panel of Fig. 4) near $360 \mathrm{~K}$ within the TTL. (The red points (left curve) are discussed in Sect. 3.4.)

For placing the measurements into a more general perspective a summary of the data is provided in the left panel of Fig. 6. The vertical profiles from Brazil, Burkina Faso, and Australia are shown (both: M-55 "Geophysica" above $350 \mathrm{~K}$, and DLR Falcon-20 below $340 \mathrm{~K}$ ) together with previously published data (Brock et al., 1995) from extratropical latitudes (purple line) and the tropics (black line). The cold point tropopause above Ouagadougou was between 365 and $370 \mathrm{~K}$, 
above Darwin around $375 \mathrm{~K}$, and near $380 \mathrm{~K}$ over Araçatuba. The tropical profile from Brock et al. (1995) contains data from northern and southern hemispheric tropical locations between 1987 and 1994, where the Pinatubo period was removed. Between roughly $340 \mathrm{~K}$ and $440 \mathrm{~K}$ all tropical profiles exhibit remarkable closeness over the 19 years and over the different locations around the globe. At the same time the significant difference between tropical and extratropical profiles is evident (also when comparing with the left panel of Fig. 4). Apparently - somewhat in analogy to the (global) stratospheric Junge layer higher above - a kind of layer of small particles spans the tropical band with maximum mixing ratios between 340 and $390 \mathrm{~K}$. This broad maximum extends from below the TTL to above the thermal tropopause. Based on model calculations and trajectory analyses (Plöger et al., 2010; Krüger et al., 2009; Fueglistaler et al., 2004) the time for upward transport from $340 \mathrm{~K}$ to $400 \mathrm{~K}$ roughly is 1 to 2.5 months. Thus the interpretation from Brock et al. (1995), of the tropical upper troposphere being a source for stratospheric particles seems to be valid for the global tropical latitude belt. Furthermore, when disregarding the long time gaps between the samplings and ignoring the large perturbations caused by the $1991 \mathrm{Mt}$. Pinatubo eruption, the profiles in Fig. 6 suggest that the characteristics of this particle source have remained rather constant over almost two decades. At altitudes between $440 \mathrm{~K}$ and $500 \mathrm{~K}$ some differences occur, the origin of which remains unclear. For the observations in Burkina Faso a small volcanic eruption is the most likely cause (see Sect. 3.4). The increase over Brazil probably is connected with import of mid-latitude air because Araçatuba is at $22^{\circ} \mathrm{S}$ and close to the subtropical jet.

The closeness of the tropical vertical profiles allows us to formulate a parameterisation of submicron particle abundance for the use in microphysical, chemical, or global chemistry and transport models. The parameterisation $n(\theta)$ in Eq. (1) represents the tropical $n_{10}$ particle background mixing ratios in number of particles per milligram of air as measured with the COPAS systems during the 2005/2006 tropical campaigns (excluding the SCOUT-AMMA data from above $420 \mathrm{~K}$ because of the volcanic perturbation) and holds for altitudes between $360 \mathrm{~K}$ and $480 \mathrm{~K}$ :

$n(\theta)=c+A \cdot \exp (-\tau \cdot \theta)$

$c=138.04 \mathrm{mg}^{-1}, A=8.4038 \times 10^{12} \mathrm{mg}^{-1}$,

and $\tau=0.060044 \mathrm{~K}^{-1}$.

A parameterisation according to Eq. (1) with different coefficients can be similarly derived from the Brock et al. (1995), data which then represents the time period from 1987 until 1994 and is valid between $360 \mathrm{~K}$ and $500 \mathrm{~K}: c=67.605 \mathrm{mg}^{-1}, A=7.2198 \times 10^{11} \mathrm{mg}^{-1}$, and $\tau=$ $0.053193 \mathrm{~K}^{-1}$.

Both parameterisations (see right panel of Fig. 6) are close to each other for potential temperatures below $420 \mathrm{~K}$ and above they are in agreement within a factor of two. The increase observed at higher altitudes with respect to the data

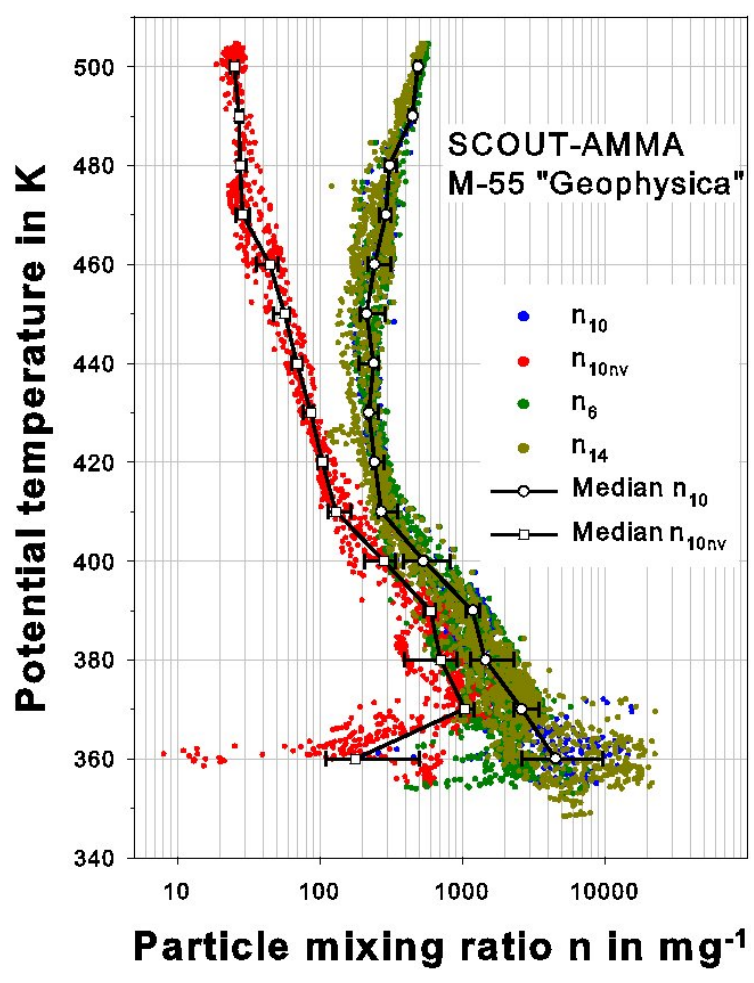

Fig. 5. Vertical profiles of ambient particle number mixing ratios $n_{i}$ from all of the M-55 "Geophysica" local flights out of Ouagadougou (Burkina Faso) in August 2006. The small points are $15 \mathrm{~s}$ averages and the open symbols represent medians of $10 \mathrm{~K}$ bins with $25 \%$ and $75 \%$ percentiles. The red points are the values for non-volatile particles $\left(n_{10 n v}\right)$. The cold point tropopause during SCOUT-AMMA was roughly between 365 and $370 \mathrm{~K}$.

from Brock et al. (1995), is of unknown origin. However the difference in number mixing ratios is small enough that for most practical purposes - both sets of parameters can be used.

To further compare the M-55 "Geophysica" measurements with other tropical data, Fig. 7 juxtaposes the 2005/2006 profiles from Burkina Faso, Brazil and Northern Australia with results from the two NASA operated research aircraft WB-57F and DC-8. These measurements are from the campaigns: ACCENT (1999), SOLVE (1999), CrystalFace (2002), SOLVE2 (2003), the AURA Validation Experiment (2004, 2005, 2006) and TC4 (2007). The latitudinal range covered by the data extends from south of $23^{\circ} \mathrm{N}$ to north of $23^{\circ} \mathrm{S}$ (with the major part north of $5^{\circ} \mathrm{S}$ ). The M-55 "Geophysica" data fit well into the range of values given by the NASA DC-8 and WB-57F measurements, which again demonstrates the uniformity of the tropical particle layer between the continents. Only above West Africa between $370 \mathrm{~K}$ and $390 \mathrm{~K}$ the mixing ratios seem to be slightly higher than over the other locations. Also, the West African profiles during SCOUT-AMMA significantly deviate towards higher particle number mixing ratios above $430 \mathrm{~K}$ due to a volcanic 


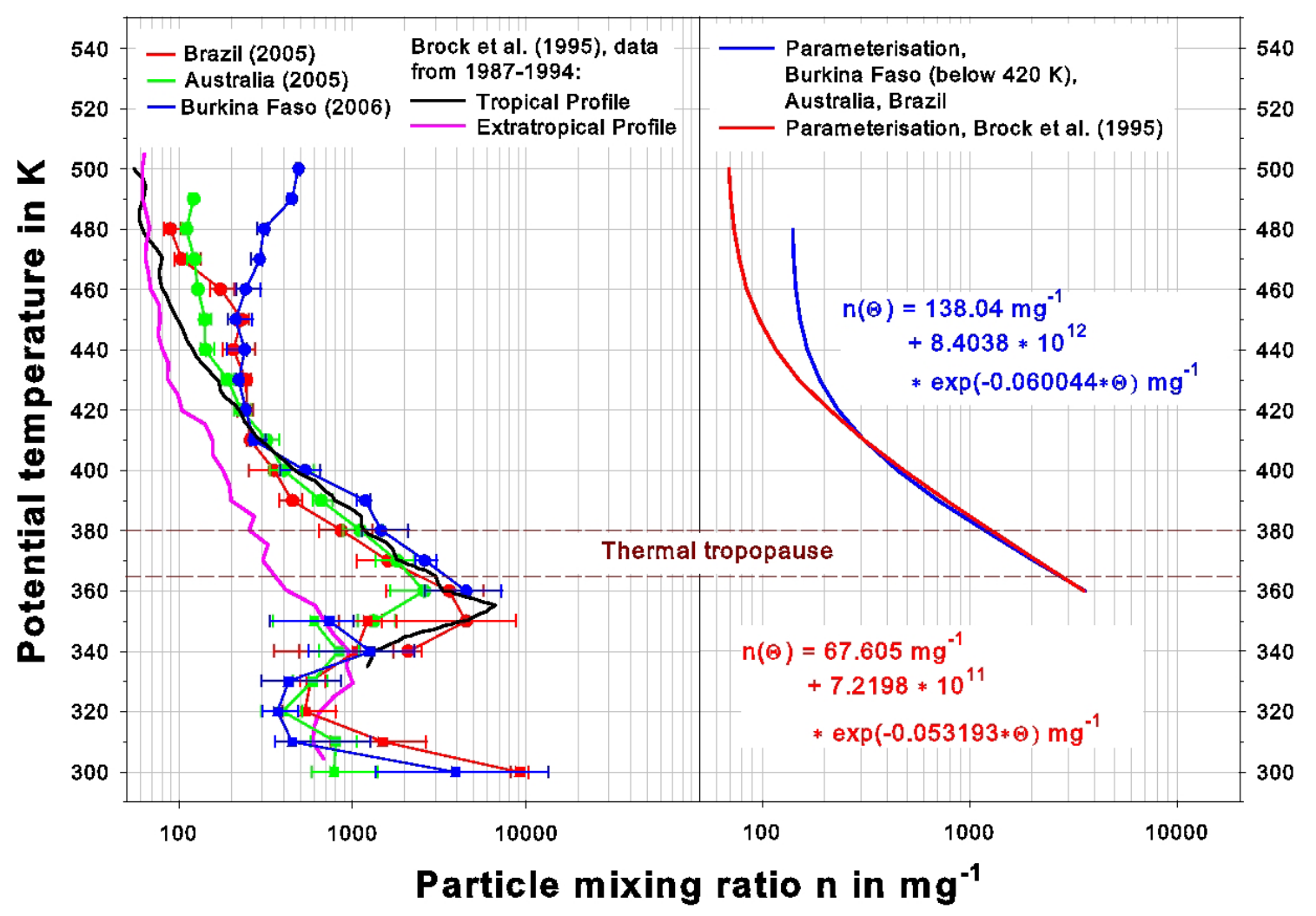

Fig. 6. Summary of all tropical profiles for submicron particle mixing ratios $n$ from 2005 and 2006. The solid symbols in the left panel are $10 \mathrm{~K}$ potential temperature bins with medians, $25 \%$, and $75 \%$ percentiles. The black (purple) line shows the results from Brock et al. (1995), representing tropical (extra-tropical) measurements with the NASA ER-2 between 1987 until 1994. The symbols with circles are $n_{6}$ (red and green), and $\mathrm{n}_{10}$ (blue) COPAS data from the M-55 "Geophysica". The measurements below $350 \mathrm{~K}$ are from the DLR Falcon 20 (red $-n_{13}$; blue $-n_{10}$; green $-n_{5}$ ). Right panel: Two parameterisations derived from the $n_{6}, n_{10}$ vs. potential temperature $(\Theta)$ data in the left panel. The lowest and highest levels of the cold point tropopause for SCOUT-AMMA, TROCCINOX, and SCOUT-O3 are indicated by the lines.

eruption (see Sect. 3.4). Clearly, considering the large scatter in the data for each potential temperature level in Fig. 7 the parameterisations according to Eq. (1) can serve only as guideline.

In Fig. 8 the correlations between the submicron particle mixing ratios and concurrent in-situ measurements of $\mathrm{N}_{2} \mathrm{O}$, ozone and $\mathrm{CO}$ are presented in order to provide some "mapping" of the aerosol data on trace gases related to atmospheric dynamics. Since the gas phase variables are measured in different sampling periods (from $1 \mathrm{~s}$ for ozone, $4 \mathrm{~s}$ for $\mathrm{CO}$, to $90 \mathrm{~s}$ of $\mathrm{N}_{2} \mathrm{O}$ ), and because the data are binned in $10 \mathrm{~K}$ potential temperature intervals, the number of resulting vertical profile data points is not large. There is a positive correlation between $\mathrm{CO}$ and the particle mixing ratio because of the import of pollution from upwind tropospheric sources like Asia and India for SCOUT-AMMA (Law et al., 2010) and from Indonesia (in connection with strong convective activity there) for Darwin (Brunner et al., 2009). Real et al. (2010) showed that biomass burning activities took place in Central Africa at the time of the SCOUT-AMMA campaign and that these significantly influenced the air over
West Africa. Air parcels of a given CO abundance contained higher aerosol loadings (upper "branch" in the middle panel of Fig. 8) for West Africa and Australia than for Brazil (lower "branch"). This probably for the most part reflects the different intensities of the biomass burning activities in the three regions. The correlation between the mixing ratios of $\mathrm{N}_{2} \mathrm{O}$ and the particles is compact with respect to the data from the different locations. The increase in particle mixing ratios with decreasing $\mathrm{N}_{2} \mathrm{O}$ over West-Africa (red squares in the left panel of Fig. 8) is due to the influence of the volcanic eruption as discussed in Sect. 3.4. Under non volcanic conditions the correlation probably follows the Brazil data (asterisks). For comparison one data point $(266 \mathrm{ppbv}$ of $\mathrm{N}_{2} \mathrm{O}, 17$ particles $\mathrm{mg}^{-1}$ ) is shown as median of 97 measurements with $25 \%$ and $75 \%$ percentiles for both, $\mathrm{N}_{2} \mathrm{O}$ and particle mixing ratios. This data is from the lower part and the outflow region of the 1992 northern hemispheric polar vortex. While $\mathrm{N}_{2} \mathrm{O}$ has a long lifetime, is well mixed within the troposphere, and has only one sink in the stratosphere, the ozone abundance is influenced by tropospheric photochemical sources and is not well suited as dynamical tracer 
in particular in the tropics. As Law et al. (2010) demonstrate, this might lead to differences in lower TTL gradients because the ozone concentrations in the TTL vary significantly in dependency of location and season. For these reasons it is not surprising that the data from the campaigns are on different "branches" of the correlations shown in the right panel of Fig. 8. Correlations between ozone and submicron particle mixing ratios with similar shape were described in Borrmann et al. (1995), for the lower part and the outflow region of the polar vortex. For comparison a parameterisation of the corresponding NASA ER-2 measurements from January 1992 is shown in the right panel of Fig. 8 as black line. Like the point with $\mathrm{N}_{2} \mathrm{O}=266$ ppbv this data was obtained six months after the large Mt. Pinatubo volcanic eruption and represents the altitude band from $12 \mathrm{~km}$ to $18 \mathrm{~km}$ (i.e. potential temperatures between $337 \mathrm{~K}$ and $441 \mathrm{~K}$ ). Despite this eruption the submicron particle mixing ratios were significantly below the levels encountered in the tropics in 2005 and 2006. Inside the 1991/1992 polar vortex the particle concentrations were low because of the subsidence of air from the mid-stratosphere and because at the time of the measurements not much Pinatubo aerosol had yet penetrated into the vortex interior. In this scenario ozone could well be used as dynamical tracer in correlations with the measured (accumulation mode) particle mixing ratios (Borrmann et al., 1995) roughly for time scales of up to 10 months.

\subsection{UT/LS vertical profiles of submicron particle num- ber densities from mid-latitudes between 1999 and 2006}

The data available from the test and transfer flights allow us to assess the variability of the particle number concentrations at northern-hemispheric mid-latitudes. The measured $N_{10}$ concentration data are shown in Fig. 9 as function of pressure altitude and potential temperature for various $\mathrm{Eu}-$ ropean locations as well as for a large number of balloon flights from Laramie, Wyoming, USA (see Deshler et al., 2003). These mid-latitude profiles are remarkably close together above $15 \mathrm{~km}$, such that a parameterisation (including the balloon data) with respect to the potential temperature $\theta$ (for the range between 380 and $490 \mathrm{~K}$ ) can be extracted:

$N(\theta)=A_{0}+A_{1} \cdot \exp \left(-\tau_{1} \cdot \theta\right)+A_{2} \cdot \exp \left(-\tau_{2} \cdot \theta\right)$,

with coefficients: $A_{0}=6.8548 \mathrm{~cm}^{-3}$,

$A_{1}=2.6827 \times 10^{8} \mathrm{~cm}^{-3}, A_{2}=4.6062 \times 10^{9} \mathrm{~cm}^{-3}$, $\tau_{1}=0.040062 \mathrm{~K}^{-1}, \tau_{2}=0.047782 \mathrm{~K}^{-1}$.

Here the particle number concentration $N$ (in $\mathrm{cm}^{-3}$ ) is calculated as function of $\Theta$ (in $\mathrm{K}$ ) and to obtain the mixing ratio the corresponding factor including ambient pressure and temperature needs to be applied. (We provide the concentration profiles here rather than the corresponding mixing ratios because the temperature measurement system on the M-55 "Geophysica" was changed and tested and as consequence we do not have reliable data for several flights.)

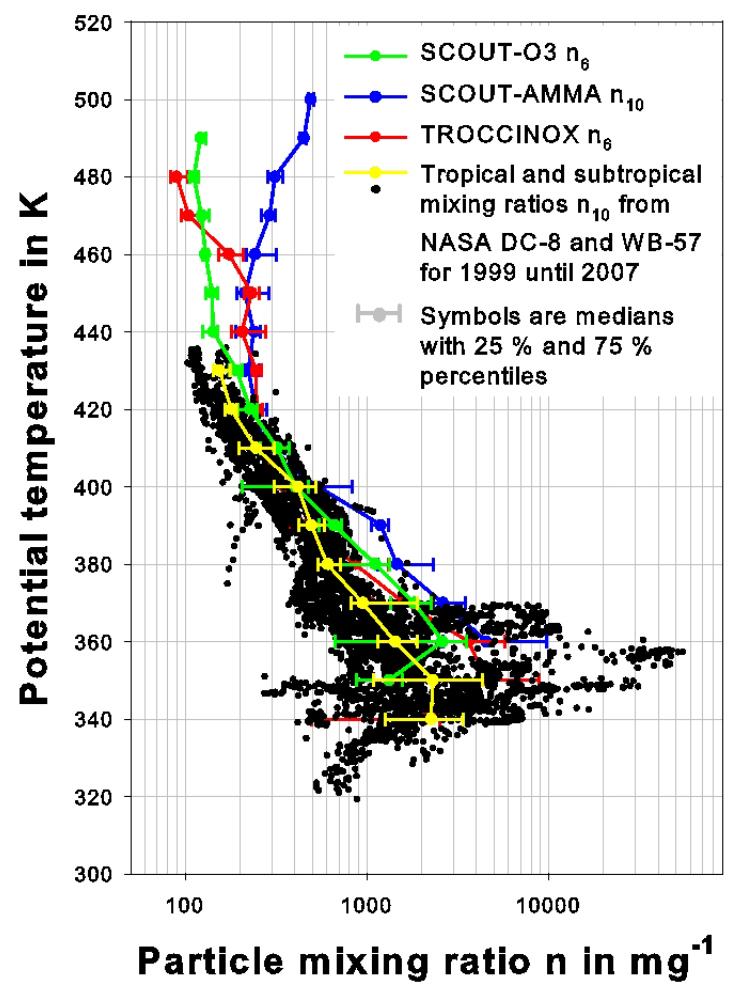

Fig. 7. Overview over the available tropical and subtropical insitu aircraft measurements of submicron particle mixing ratios. The black points are data from the Caribbean, the Gulf of Mexico, and Hawaii from 1999 until 2007 and the yellow symbols denote their medians and percentiles (Source: University of Denver group). The coloured lines show the M-55 "Geophysica" measurements from Northern Australia (green), Burkina Faso (blue) and Brazil (red).

The closeness of the profiles indicates that in the mid-latitude lower stratosphere under background conditions the submicron particle population is under a stable equilibrium regime starting roughly 5 years after the 1991 Mt. Pinatubo eruption. In the time between 1999 and 2006 there was no major volcanic eruption and as result the background particle number concentrations were significantly below the levels of the period between the 1982 and 1991 eruptions of El Chichon and Mt. Pinatubo (Borrmann et al., 1993, 2000; Brock et al., 1993). In the same time between 1999 and 2006 a significant increase of commercial air traffic occurred as the growth rates of revenue passenger miles consistently were near $5 \%$ per year according to IATA data. It had been conjectured that rising commercial air traffic may lead to increases in stratospheric aerosol loadings (Hoffman, 1990). Judging from the - admittedly sparse - data sets in Fig. 9 most likely there are no striking increases in total particle number densities despite the strong changes in air traffic. If the air traffic influences particles with sizes above the accumulation mode in the stratospheric background aerosol these influences may be 


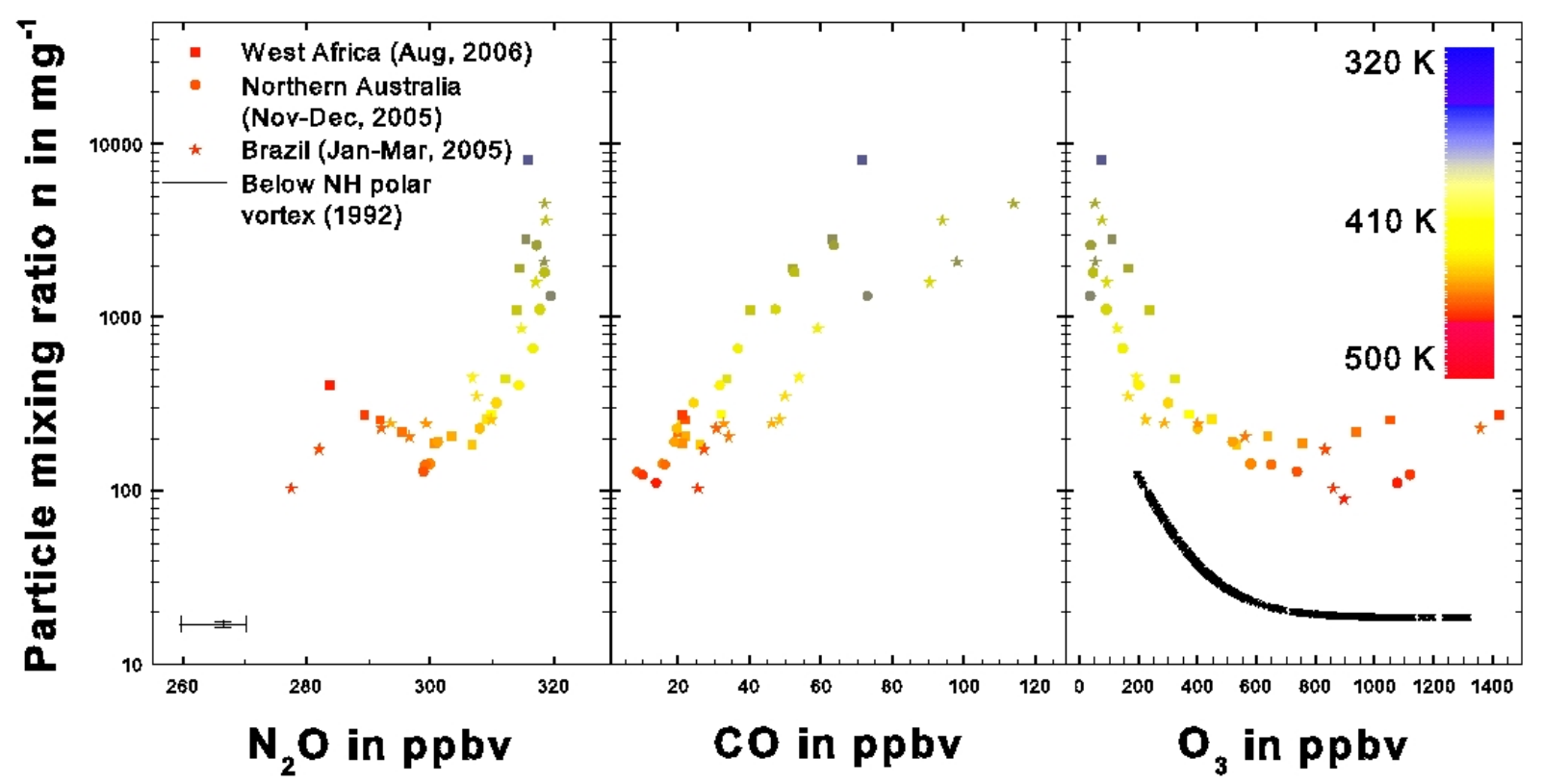

Fig. 8. Correlation of submicron particle mixing ratios $n$ with trace gases $\mathrm{N}_{2} \mathrm{O}, \mathrm{CO}$, and ozone for West Africa, Northern Australia, and Brazil. The data points are medians of $10 \mathrm{~K}$ potential temperature intervals. The black curve in the right panel is a parameterisation of the 1992 NASA ER-2 data from below the northern hemispheric polar vortex for comparison (see text for details).

more subtle. It is important to keep in mind that at altitudes below $\approx 400 \mathrm{~K}$ the mid-latitudes are "flushed" with air from the tropics between July and October. During the remainder of the year the Brewer-Dobson circulation leads to an import of air from above. For this reason there is some variability in the profiles because these were measured at different seasons throughout the years.

\subsection{Volcanic influence on the UT/LS aerosol over West Africa}

The particle number mixing ratios in the vertical profiles from West Africa (2006) in Figs. 5, 6 and 7 show significant deviations from the other tropical profiles for altitudes above $430 \mathrm{~K}$. These are atmospheric features because such deviations were not observed in the vertical profiles over Verona, Italy, and Marrakech, Morocco, during the transfer flights. An intercomparison of the COPAS data measured from the M-55 "Geophysica" over Ouagadougou, Burkina Faso, in August 2006, and the balloon borne CPC measurements of the University of Wyoming group over Niamey, Niger, $\left(2^{\circ} 10^{\prime} 8^{\prime \prime}\right.$ E longitude, $13^{\circ} 29^{\prime} 11^{\prime \prime} \mathrm{N}$. latitude) on 31 July 2006 is shown in Fig. 10. Considering the different nature of the two platforms (i.e., fast flying aircraft vs. slowly ascending balloon) and the difference in location (Ouagadougou vs. Niamey with $\approx 430 \mathrm{~km}$ separation) the agreement between the two different instruments is good for the theta levels between 360 and $460 \mathrm{~K}$. In the balloon data the rate of increase in mixing ratios with altitude is stronger than for COPAS at theta levels above $450 \mathrm{~K}$. Furthermore, the balloon data show that the enhanced particle number densities are reaching up to $\approx 550 \mathrm{~K}$, forming a broad layer. The presence of this layer is confirmed also by Khaykin et al. (2009), where all balloon flights from Niamey are presented. Because the enhancement does not occur in the mid-latitude and subtropical profiles over Verona, Italy, and Marrakesh, Morocco, the stratospheric enhancement seems to be confined to the tropical belt. The most likely cause of these increases is the eruption of the tropical stratovolcano Soufrière Hills on Montserrat Island in the West Indies $\left(16^{\circ} 42^{\prime} 56^{\prime \prime} \mathrm{N}\right.$. latitude, $62^{\circ} 11^{\prime} 8^{\prime \prime} \mathrm{W}$ longitude, $1050 \mathrm{~m}$ a.s.1.), which occurred on 20 May 2006 (Carn et al., 2007) and roughly two months before the measurements in West Africa. The amount of $\mathrm{SO}_{2}$ injected into the stratosphere was estimated to be $0.1 \mathrm{Tg}$ of sulphur (i.e., the equivalent to $0.2 \mathrm{Tg}$ of $\mathrm{SO}_{2}$ ) based on satellite observations (Carn et al., 2007). In Fig. 5 the left curve (red points, square symbols) shows the measurements of nonvolatile particle mixing ratios $n_{10 \mathrm{nv}}$ from the heated COPAS channel. Above $420 \mathrm{~K}$ the absolute number of non-volatile particles decreases with altitude with increasing total particle number mixing ratios. Thus the ratio of non-volatile to total particle mixing ratios strongly declines with height. Also, the MAS backscatter sonde reported enhanced backscatter ratio with no depolarisation in this altitude region with peak values of 1.3 for the backscatter at $19.3 \mathrm{~km}$. Profiles measured by the balloon borne version of MAS, which was launched on different balloon missions from Niamey during SCOUT-AMMA, also regularly detected such increases in 


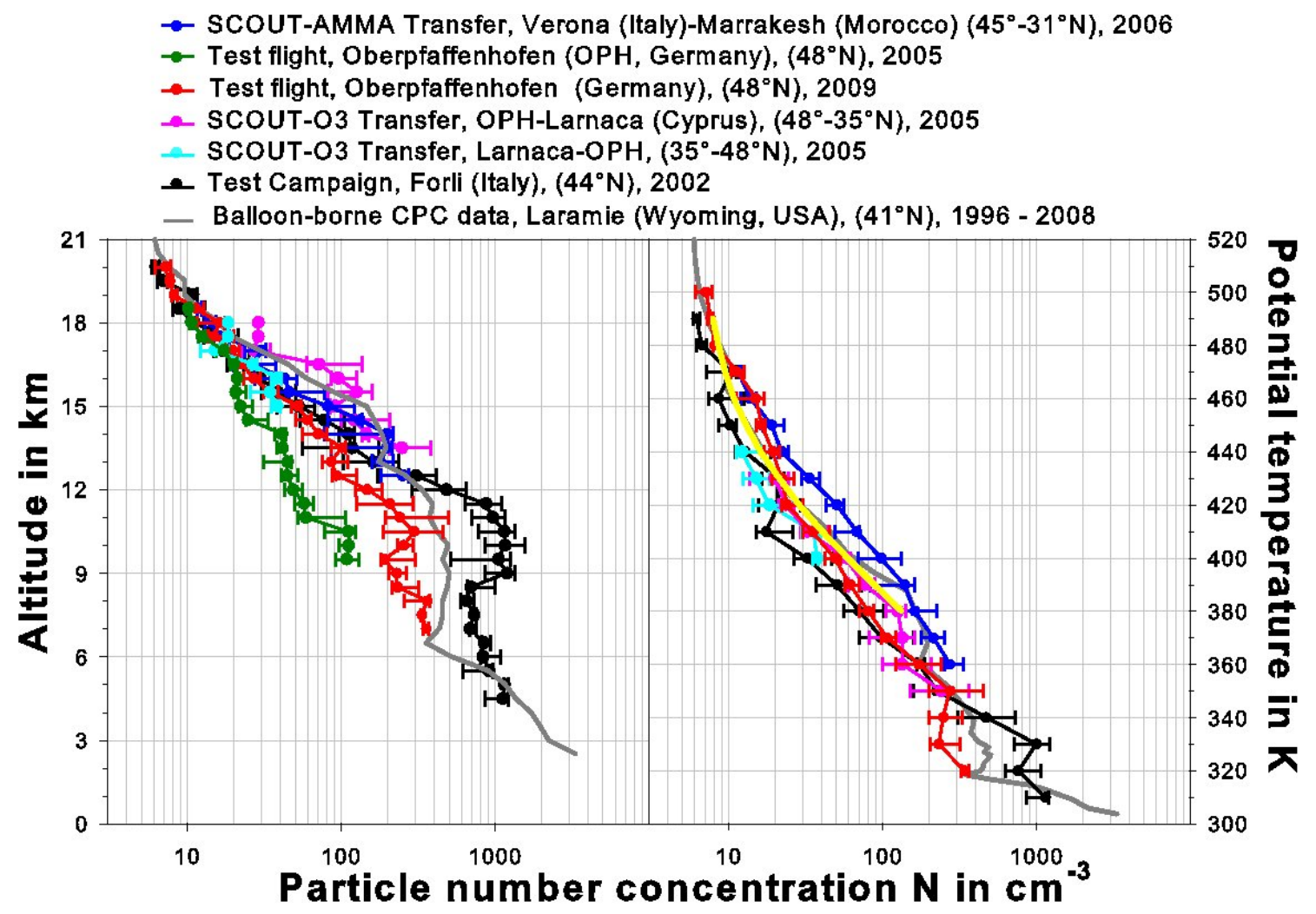

Fig. 9. Mid-latitude vertical profiles of COPAS particle number densities $\left(N_{10}\right)$ from the M-55 "Geophysica" flights between 2002 and 2006 (as medians of $10 \mathrm{~K}$ altitude bins and $25 \%, 75 \%$ percentiles). The grey line is an average profile from balloon borne CPC measurements of the University of Wyoming from 1996 until 2008. The yellow curve is the parameterisation of Eq. (2) as derived from the $380 \mathrm{~K}$ to $490 \mathrm{~K}$ data of this panel (note: The left and right ordinates do not correspond to each other).

backscatter. This supports the interpretation of the aerosols being of volcanic origin, because (1) the fraction of volatile (i.e. binary sulphuric acid-water solution droplets) particles becomes larger with altitude (see also Sect. 3.5) and (2) the non-depolarisation of the aerosol indicates the presence of spherical (i.e., liquid phase) particles. Although the Soufrière Hills eruption provided the largest single sulphur input into the stratosphere between 1991 and 2006, its amount was small compared to the $20 \mathrm{Mt}$ of $\mathrm{SO}_{2}$ from Mt. Pinatubo (Chapter 3 in WMO, 1999). Prata et al. (2007) showed by means of satellite cloud top temperature measurements that the overshooting of the eruption plume core from Soufrière Hills reached the stratosphere and the evolution of the cloud was tracked for example by CALIPSO measurements of $\mathrm{SO}_{2}$ (e.g., http://earthobservatory.nasa.gov). The eruption cloud developed inhomogeneities three days after the eruption and the air masses containing the volcanic $\mathrm{SO}_{2}$ were confined mostly within the tropical belt while moving towards Africa. Such inhomogeneity is reflected in the particle mixing ratio data of the vertical profile in Fig. 10. Over Niamey, Niger, above $475 \mathrm{~K}$, values near 1000 particles per milligram of air were encountered on 31 July 2006, while the air masses sampled over Burkina Faso 4-13 days later contained mixing ratios only half as high. Between $375 \mathrm{~K}$ and $450 \mathrm{~K}$ the instruments show identical values for both locations. From the vertical profile two months after the eruption it can be concluded, that the ageing of the volcanic aerosol had not yet proceeded to the point where sedimentation of the particles from the layer above $18 \mathrm{~km}$ enhances the number densities found in the TTL. Similarly, after the Pinatubo eruption it took more than six months (in mid-latitudes) until the aerosol at the tropopause had significantly increased (Borrmann et al., 1997; Keim et al., 1996).

\subsection{Non-volatile components in the tropical UT/LS sub- micron aerosol}

From the values for $N_{10 \mathrm{nv}}$ and $N_{10}$ it is possible to calculate the non-volatile fraction, $f$. This is the number density $N_{10 \mathrm{nv}}$ of particles which do not evaporate when heated to $250^{\circ} \mathrm{C}$ divided by the total number concentration $N_{10}$ of ambient particles. The resulting vertical profiles from the tropical data are shown in Fig. 11 for South America, Northern Australia, and for West Africa. The two profiles over Australia and Burkina Faso exhibit a broad maximum for $f$ between $360 \mathrm{~K}$ and $460 \mathrm{~K}$ with its highest value at $400 \mathrm{~K}$. 


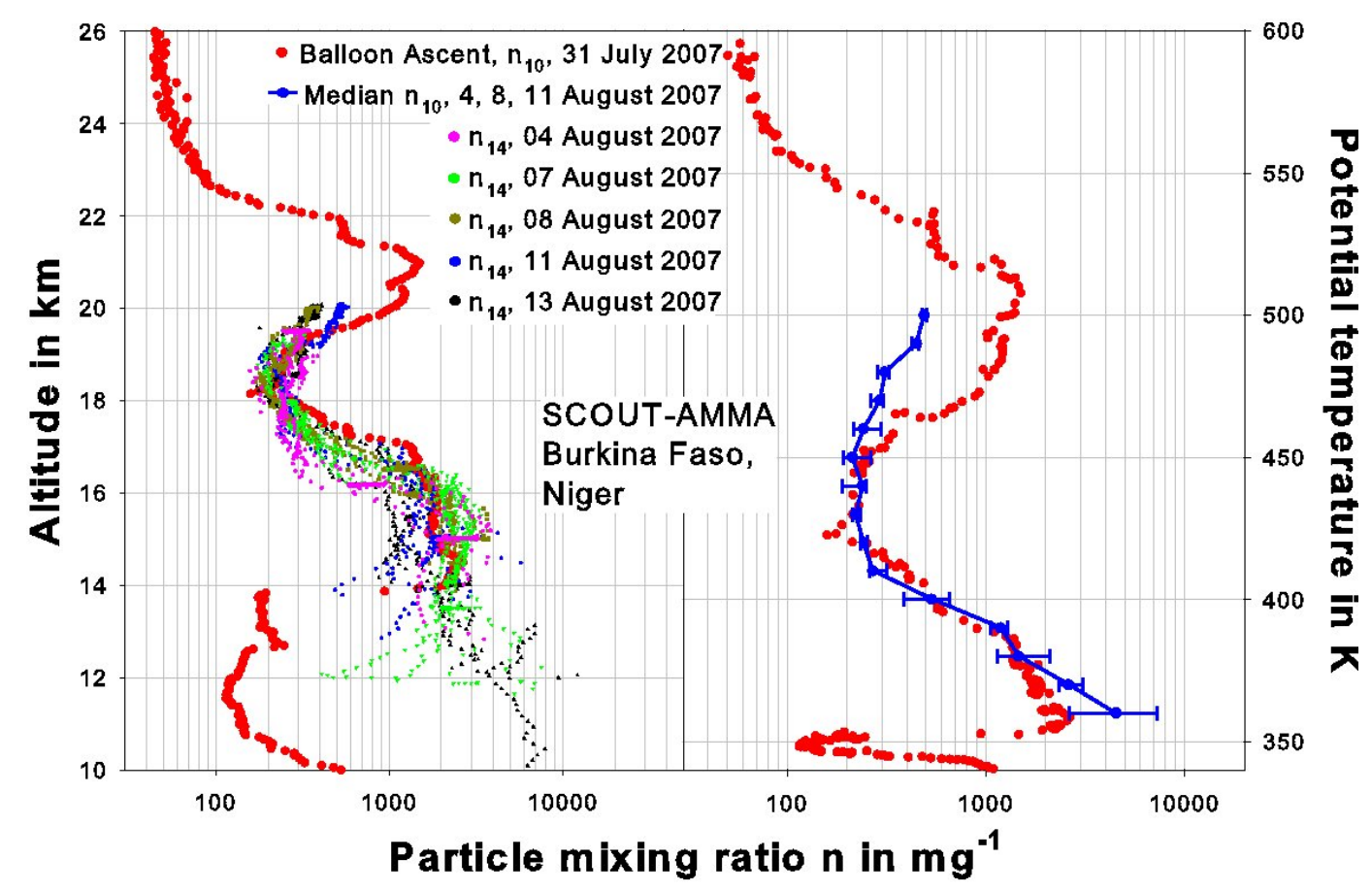

Fig. 10. Intercomparison of the individual $n_{10}$ particle mixing ratio measurements of the balloon launch on 31 July 2006 from Niamey, Niger, with the $n_{14}$ data of all local M-55 "Geophysica" flights from Ouagadougou (Burkina Faso). The COPAS data points in the left panel represent $15 \mathrm{~s}$ averages while the balloon data (larger red points) are averaged over $5 \mathrm{~s}$. In the right panel the same data are displayed as function of potential temperature with the blue points designating the median (with $25 \%$ and $75 \%$ percentiles) from $10 \mathrm{~K}$ altitude bins (note: The left and right ordinates do not correspond to each other).

This peak roughly extends from the thermal tropopause well into the lowermost stratosphere and includes the upper part of the TTL. Such a maximum is not present in the data from Brazil where the ratio $f$ remains fairly constant around $20 \%$ from $390 \mathrm{~K}$ to $490 \mathrm{~K}$. At $360 \mathrm{~K}$ the ratio $f$ attains values near $10 \%$. (For comparison: Values as high as $70 \%$ to $80 \%$ were reported by Curtius et al. (2005), for meteoric dust subsiding inside the polar vortex within the same potential temperature band.) We believe this decrease in non volatility from $400 \mathrm{~K}$ to $360 \mathrm{~K}$ in Fig. 11 is not an instrumental artifact, because (1) the efficiency of the pre-heating device of the $N_{10 \mathrm{nv}}$ channel was extensively characterised in the laboratory (Weigel et al., 2009) for low pressures ( $70 \mathrm{hPa}$ to $300 \mathrm{hPa}$ ) and (2) the values for $\mathrm{f}$ from the DLR Falcon-20 well match those from the M-55 "Geophysica" at $350 \mathrm{~K}$ for SCOUT-AMMA while the difference for TROCCINOX at $350 \mathrm{~K}$ is not large.

With altitude above roughly $400 \mathrm{~K}$ the non-volatile fraction $f$ decreases in all profiles (except for Brazil), which indicates that the higher one probes into the stratosphere the more the volatile sulphuric acid-water solution droplets dominate the aerosol. This certainly is the case for the measurements over West-Africa, where $f$ is below $10 \%$ at the highest altitudes because of the volcanic contribution. A significant increase, however, is observed in the profiles over Northern Australia above $460 \mathrm{~K}$ for which we do not have an expla- nation. The lowest levels of $f$ (near 5\%) observed at high altitudes over West Africa are most likely a consequence of the Caribbean volcanic eruption because after an eruption the oxidation of the gaseous $\mathrm{SO}_{2}$ to $\mathrm{H}_{2} \mathrm{SO}_{4}$ leads to binary $\mathrm{H}_{2} \mathrm{SO}_{4} / \mathrm{H}_{2} \mathrm{O}$ solution droplets.

It is difficult to find conclusive explanations for the observed vertical profiles of $f$ without additional measurements and model calculations. Despite the lower non-volatile fraction the absolute number densities of non-volatile particles below the tropopause still is similar or larger than in the lower stratosphere. This follows from the higher total ambient particle number densities as can be seen for example in Fig. 5. For the differing profile from Brazil it should be borne in mind that the flights were performed at latitudes near $22^{\circ} \mathrm{S}$, which is at the Southern edge of the tropical belt and close to the subtropical jet. Differences between the dry and wet seasons, the position of the ITCZ, and the level of biomass burning activity play a role for the volatility of the sampled particles. The non-volatile cores of the particles most likely are not a result of gas-to-particle conversion processes. This implies that these particles originate from the local or remote boundary layer and may have undergone in-cloud processing during upward transport. The minimum of $f$ at $360 \mathrm{~K}$ might be a result of cloud scavenging (or ice cloud formation) at or below the tropopause. The volatile 


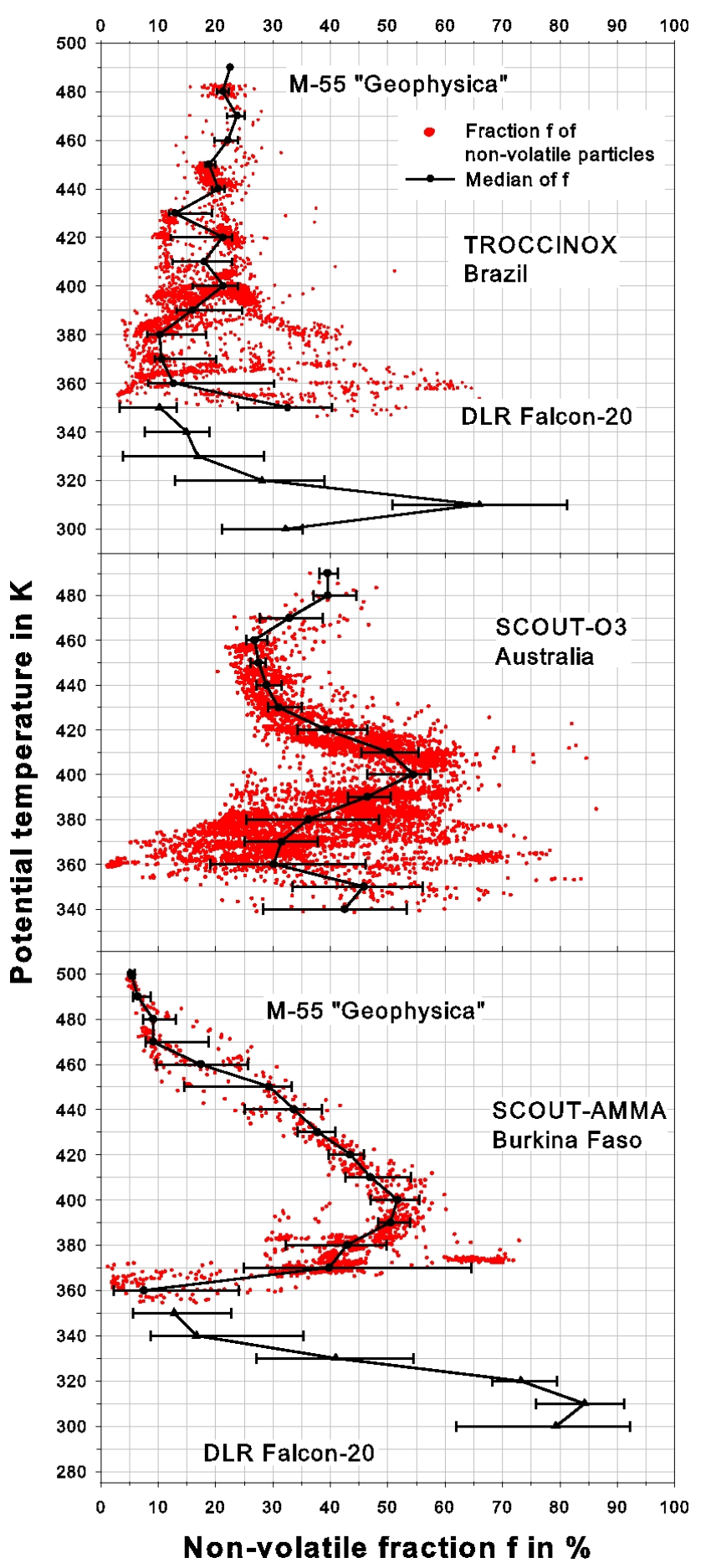

Fig. 11. Ratio $f$ of non-volatile particle number concentration $N_{10 n v}$ to total ambient particle number density $N_{10}$ as function of altitude (points: $15 \mathrm{~s}$ flight time averages; Symbols: medians, $25 \%$ and $75 \%$ percentiles of $10 \mathrm{~K}$ bins). The data are from the local flights over Araçatuba (Brazil, 2005), Darwin (Australia, 2005), West Africa (red points and line above $360 \mathrm{~K}$ ). Similarly, thermodenuder measurements of $N_{7}$ from the DLR Falcon-20 are included (without individual data points) where available for potential temperature levels below $350 \mathrm{~K}$.
$\mathrm{H}_{2} \mathrm{SO}_{4} / \mathrm{H}_{2} \mathrm{O}$ droplets are subject to scavenging also. However for those droplets there would be two sources, namely in-situ formation in the TTL and transport from below, while for the non-volatile particles there is only uplift from below. This could result in a decrease of $f$ at the tropopause. Clearly such arguments remain speculative without detailed modelling and further measurements. Also, without direct measurements of the chemical composition of these particles (e.g., like in Murphy et al., 1998; Froyd et al., 2009, 2010; or Schmale et al., 2010) no conclusive explanation for the observed features in the profiles can be given. If - as concluded by Brock et al. (1995) - the tropical upper troposphere is a source reservoir of aerosol particles for the global stratosphere, then our data suggest that those particles arriving in the tropical stratosphere contain significant amounts of nonvolatile components. Following Froyd et al. (2009), this can be due to the fact, that convection rapidly carries air from the boundary layer aloft and that often biomass burning residues reach the tropical UT/LS.

\section{Summary and conclusions}

In this contribution we present aircraft-borne in-situ measurements of submicron particle abundance and volatility from the 9 to $12 \mathrm{~km}$ altitude range, the UT/LS, and the TTL over Southern Brazil (TROCCINOX campaign, 2005), West Africa (SCOUT-AMMA, including balloon-borne measurements from Niger, 2006), and Northern Australia (SCOUTO3, 2005). Also measurements are considered from previous campaigns with NASA high altitude research aircraft in Hawaii and Costa Rica dating back to 1999.

The transfer flights from Europe to the tropical campaign locations showed that at potential temperature levels above $367 \mathrm{~K}$ the ambient particle number densities range from $20 \mathrm{~cm}^{-3}$ at higher latitudes to values around $100 \mathrm{~cm}^{-3}$ in the tropics and that the geographical distribution of the particle abundance was rather homogeneous along the different latitude bands.

The vertical profiles of the particle mixing ratio over West Africa, Brazil and Northern Australia between $55^{\circ} \mathrm{N}$ to $20^{\circ} \mathrm{S}$ are remarkably similar within the potential temperature band from $340 \mathrm{~K}$ to $430 \mathrm{~K}$ and fit well into the earlier data from 1987 to 1994 (Brock et al., 1995). The tropical vertical profiles all show a broad maximum of particle mixing ratios in the altitude band between $340 \mathrm{~K}$ and $390 \mathrm{~K}$. Since the maximum extends from below the TTL to above the thermal tropopause, this supports the suggestion by Brock et al. (1995), that the tropical aerosol layer acts as a continuous source of particles for the maintenance of the global stratospheric Junge aerosol layer. Above $430 \mathrm{~K}$, the profiles from 2005 and 2006 differ from the 1987 to 1994 data by showing higher values at all levels up to roughly $500 \mathrm{~K}$. Only for the vertical profiles over West Africa from 2006 do we have an explanation: the volcanic eruption of Soufrière Hills on 
Montserrat is the likely cause of that increase. However, at all altitudes the data are reasonably compact and a parameterisation for use in models could be extracted.

Correlations of the measured aerosol mixing ratios with $\mathrm{N}_{2} \mathrm{O}$ and ozone exhibit compact relationships for all three tropical campaigns. The volcanic enhancement over West Africa caused high particle mixing ratios to be associated with low $\mathrm{N}_{2} \mathrm{O}$. Correlations with $\mathrm{CO}$ exhibit a likelihood - but not a compact correlation - of high particle abundance with high CO. Probably this is a result of the different biomass burning source characteristics over the three continents.

Analyses of the vertical profiles at mid-latitudes show that the particle number densities as function of altitude remained fairly constant with time between 1996 and 2008 above $15 \mathrm{~km}$. No major trends of increases or decreases can be discerned from the available (and small) data base.

The measurements of the non-volatile number fraction of the submicron particles provided useful - albeit limited - additional information on the particle properties in the tropical UT/LS region. In the profiles over West Africa the proportion of volatile particles increases with altitude. This is in agreement with the notion that at higher altitudes binary sulphuric acid/water solution droplets are the major aerosol constituents resulting from the volcanic eruption. Over West Africa and Northern Australia a broad maximum with 55\% of the particles containing non-volatile cores was found directly at and above the tropical tropopause. The profiles from Brazil exhibit constant non-volatile fractions of $20 \%$ to $25 \%$, without maximum, for altitudes above $390 \mathrm{~K}$. The measurements in Brazil took place close enough to the subtropical jet region, such that mixing with extratropical air masses may have led to the differing profiles here. If the tropical upper troposphere provides a reservoir of particles for the stratospheric Junge aerosol layer, then these "source"-particles consist of not only sulphuric acid and water, but also of nonvolatile components. A variety of processes may be responsible for the observed vertical profiles of non volatile particle number densities including deep convection of boundary layer air, biomass burning residues being uplifted into the tropical UT/LS, and long-range transport of pollutants.

Advanced instrumentation and modeling, as well as more field campaigns specifically dedicated to the properties of the aerosols and clouds in the TTL and the tropical UT/LS are much needed in order to clarify some of these issues, which have strong links to radiation, climate, and atmospheric chemistry. Better geographical coverage with tropical UT/LS data is very important, especially over Africa, South East Asia and the oceans.

Acknowledgements. The SCOUT-O3 and TROCCINOX projects were funded by the European Commission through Contracts 505390-GOCE-CT-2004-505390 and EVK2-2001-00122. The M55 "Geophysica" campaign was supported by the EEIGGeophysica Consortium, CNRS-INSU, EC Integrated Projects AMMA-EU (Contract Number 004089-2), SCOUT-O3, CNES, and EUFAR. The DLR Falcon-20 campaigns were funded through TROCCINOX, SCOUT-O3, AMMA-EU, and DLR. The balloonborne experiments of the University of Wyoming received funding from the US National Science Foundation (ATM-0437406) and J. C. Wilson acknowledges the NASA Upper Atmosphere Research Program and Radiation Sciences Program for supporting the measurements and data analysis presented here.

Based on a French initiative, AMMA was built by an international scientific group and funded by a large number of agencies, especially from France, the United Kingdom, the United States, Africa, and - for us - German sources. It has been a beneficiary of a major financial contribution from the European Community Sixth Framework Programme (AMMA-EU). Significant financial support for our activities with the M-55 "Geophysica" in Brazil, Australia, and Burkina Faso also was supplied by the Max Planck Society.

S.B. would like to extend special thanks to Susan Solomon for intense discussions, and gratefully acknowledges the support for his 2009 sabbatical from the NOAA Chemical Sciences Division in Boulder, CO, USA. The help of Andreas Kürten, (Goethe University of Frankfurt, Germany) for the primary data quality control and data collection in Darwin, Australia, is gratefully acknowledged as are helpful comments from Thomas Peter (ETHZ). We thank Stefano Balestri, Ana Alfaro Martinez (ERS), and the entire "Geophysica" crew (in particular the pilots and engineers). Also we acknowledge logistical support from the AMMA Operations Centre in Niamey, Niger. The local authorities, scientists and staff in Darwin (Australia), Araçatuba (Brazil), and Ouagadougou (Burkina Faso) were excellent hosts, and we thank for their collaboration, hospitality and often extraordinarily un-bureaucratic efficient help during these difficult and challenging campaigns in the tropical environments.

The service charges for this open access publication have been covered by the Max Planck Society.

Edited by: R. MacKenzie

\section{References}

Borrmann, S., Dye, J. E., Baumgardner, D., Wilson, J. C., Jonsson, H. H., Brock, C. A., Loewenstein, M., Podolske, J. R., and Ferry, G. V.: In-situ measurements of changes in stratospheric aerosol and the N2O-aerosol relationship inside and outside of the polar vortex, Geophys. Res. Lett., 20, 2559-2562, 1993.

Borrmann, S., Dye, J. E., Baumgardner, D., Proffitt, M., Margitan, J., Wilson, J. C., Jonsson, H. H., Brock, C. A., Loewenstein, M., Podolske, J. R., and Ferry, G. V.: Aerosols as dynamical tracers in the lower stratosphere: The aerosol vs. ozone correlations after the Mount Pinatubo Eruption, J. Geophys. Res., 100, 11147-11156, 1995.

Borrmann, S., Solomon, S., Dye, J. E., Baumgardner, D., Kelly, K. K., and Chan, K. R.: Heterogeneous reactions on stratospheric background aerosols, volcanic sulfuric acid droplets, and type I PSCs: The effects of temperature fluctuations and differences in particle phase, J. Geophys. Res., 102, 3639-3648, 1997.

Brock, C. A., Jonsson, H. H., Wilson, J. C., Dye, J. E., Baumgardner, D., and Borrmann, S.: Relationships between optical extinction, backscatter and aerosol surface and volume in the strato- 
sphere following the eruption of Mt. Pinatubo, Geophys. Res. Lett., 20, 2555-2558, 1993.

Brock, C. A., Schröder, F., Kärcher, B., Petzold, A., Busen, R., and Fiebig, M.: Ultrafine particle size distributions measured in aircraft exhaust plumes, J. Geophys. Res., 105, 26555-26567, 2000.

Brock, C. A., Hamill, P., Wilson, J. C., Jonsson, H. H., and Chan, K. R.: Particle formation in the upper tropical troposhere - A source of nuclei for the stratospheric aerosol, Science, 270, 1650-1653, 1995.

Brunner, D., Siegmund, P., May, P. T., Chappel, L., Schiller, C., Müller, R., Peter, T., Fueglistaler, S., MacKenzie, A. R., Fix, A., Schlager, H., Allen, G., Fjaeraa, A. M., Streibel, M., and Harris, N. R. P.: The SCOUT-O3 Darwin Aircraft Campaign: rationale and meteorology, Atmos. Chem. Phys., 9, 93-117, doi:10.5194/acp-9-93-2009, 2009.

Buontempo, C., Cairo, F., Di Donfrancesco, G., Morbidini, R., Viterbini, M., and Adriani, A.: Optical measurements of atmospheric particles from airborne platform: in-situ and remote sensing instruments for balloons and aircrafts, Ann. Geophys.-Italy, 49, 57-64, 2006.

Cairo, F., Adriani, A., Viterbini, M., Di Donfrancesco, G., Mitev, V., Matthey, R., Bastiano, M., Redaelli, G., Dragani, R., Ferretti, R., Rizi, V., Paolucci, T., Bernardini, L., Cacciani, M., Pace, G., and Fiocco, G.: Polar stratospheric clouds observed during the Airborne Polar ExperimentGeophysica Aircraft in Antarctica (APE-GAIA) campaign, J. Geophys. Res., 109, D07204, doi:10.1029/2003JD003930, 2004.

Cairo, F., Pommereau, J. P., Law, K. S., Schlager, H., Garnier, A., Fierli, F., Ern, M., Streibel, M., Arabas, S., Borrmann, S., Berthelier, J. J., Blom, C., Christensen, T., D’Amato, F., Di Donfrancesco, G., Deshler, T., Diedhiou, A., Durry, G., Engelsen, O., Goutail, F., Harris, N. R. P., Kerstel, E. R. T., Khaykin, S., Konopka, P., Kylling, A., Larsen, N., Lebel, T., Liu, X., MacKenzie, A. R., Nielsen, J., Oulanowski, A., Parker, D. J., Pelon, J., Polcher, J., Pyle, J. A., Ravegnani, F., Rivire, E. D., Robinson, A. D., Rckmann, T., Schiller, C., Simões, F., Stefanutti, L., Stroh, F., Some, L., Siegmund, P., Sitnikov, N., Vernier, J. P., Volk, C. M., Voigt, C., von Hobe, M., Viciani, S., and Yushkov, V.: An introduction to the SCOUT-AMMA stratospheric aircraft, balloons and sondes campaign in West Africa, August 2006: rationale and roadmap, Atmos. Chem. Phys., 10, 2237-2256, doi:10.5194/acp10-2237-2010, 2010a.

Cairo, F., G. Di Donfrancesco, M. Snels, F. Fierli, M. Viterbini, W. Frey, and S. Borrmann, A comparison of particle light backscattering and size distribution measurements in tropical cirrus clouds, Atmos. Meas. Tech. Discuss., in review, 2010b.

Carn, S. A., Krotkov, N. A., Yang, K., Hoff, R. M., Prata, A. J., Krueger, A. J., Loughlin, S. C., and Levelt, P. F.: Extended observations of volcanic $\mathrm{SO}_{2}$ and sulfate aerosol in the stratosphere, Atmos. Chem. Phys. Discuss., 7, 2857-2871, doi:10.5194/acpd7-2857-2007, 2007.

Corti, T., Luo, B. P., de Reus, M., Brunner, D., Cairo, F., Mahoney, M. J., Martucci, G., Matthey, R., Mitev, V., dos Santos, F. H., Schiller, C., Shur, G., Sitnikov, N. M., Spelten, N., Vössing, H. J., Borrmann, S., and Peter, T.: Unprecedented evidence for overshooting convection hydrating the tropical stratosphere, Geophys. Res. Lett., 35, L10810, doi:10.1029/2008GL033641, 2008.
Curtius, J., Weigel, R., Vössing, H.-J., Wernli, H., Werner, A., Volk, C.-M., Konopka, P., Krebsbach, M., Schiller, C., Roiger, A., Schlager, H., Dreiling, V., and Borrmann, S.: Observations of meteoric material and implications for aerosol nucleation in the winter Arctic lower stratosphere derived from in situ particle measurements, Atmos. Chem. Phys., 5, 3053-3069, doi:10.5194/acp-5-3053-2005, 2005.

Cziczo, D. J., Stetzer, O., Worringen, A., Ebert, M., Weinbruch, S., Kamphus, M., Gallavardin, S. J., Curtius, J., Borrmann, S., Froyd, K. D., Mertes, S., Möhler, O., and Lohmann, U.: Inadvertent climate modification due to anthropogenic lead, Nature Geoscience, 2, 333-336, 2009.

Davis, S., Hlavka, D., Jensen, E., Rosenlof, K., Schmidt, S., Borrmann, S., Frey, W., Lawson, P., Voemel, H., and Bui, T. P.: In situ and lidar observations of subvisible cirrus clouds during TC4, J. Geophys. Res., in press, 2010.

DeMott, P. J., Sassen, K., Poellot, M. R., Baumgardner, D., Rogers, D. C., Brooks, S. D., Prenni, A. J., and Kreidenweis, S. M.: African dust aerosols as atmospheric ice nuclei, Geophys. Res. Lett., 30, 1732, doi:10.1029/2003GL017410, 2003.

de Reus, M., Borrmann, S., Bansemer, A., Heymsfield, A. J., Weigel, R., Schiller, C., Mitev, V., Frey, W., Kunkel, D., Kürten, A., Curtius, J., Sitnikov, N. M., Ulanovsky, A., and Ravegnani, F.: Evidence for ice particles in the tropical stratosphere from in-situ measurements, Atmos. Chem. Phys., 9, 6775-6792, doi:10.5194/acp-9-6775-2009, 2009.

Deshler, T., Hervig, M. E., Hofmann, D. J., Rosen, J. M., and Liley, J. B.: Thirty years of in- situ stratospheric aerosol size distribution measurements from Laramie, Wyoming $\left(41^{\circ} \mathrm{N}\right)$, using balloon-borne instruments, J. Geophys. Res., 108, 4167, doi:10.1029/2002JD002514, 2003.

Ekman, A. M. L., Krejci, R., Engström, A., Ström, J., de Reus, M., Williams, J., and Andreae, M. O.: Do organics contribute to small particle formation in the Amazonian upper toposphere?, Geophys. Res. Lett., 35, L17810, doi:10.1029/2008GL034970, 2008.

Fierli, F., Orlandi, E., Law, K. S., Cagnazzo, C., Cairo, F., Schiller, C., Borrmann, S., Didonfrancesco, G., Ravegnani, F., and Volk, M.: Impact of deep convection in the tropical tropopause layer in West Africa: in-situ observations and mesoscale modelling, Atmos. Chem. Phys. Discuss., 10, 4927-4961, doi:10.5194/acpd10-4927-2010, 2010.

Fueglistaler, S., Dessler, A. E., Dunkerton, T. J., Folkins, I., Fu, Q., and Mote, P. W.: Tropical Tropopause Layer, Rev. Geophys., 47, RG1004, doi:10.1029/2008RG000267, 2009.

Fueglistaler, S., Wernli, H., and Peter, T.: Tropical troposphereto-stratosphere transport inferred from trajectory calculations J. Geophys. Res., 109, D03108, doi:10.1029/2004JD005516, 2004.

Froyd, K. D., Murphy, D. M., Sanford, T. J., Thomson, D. S., Wilson, J. C., Pfister, L., and Lait, L.: Aerosol composition of the tropical upper troposphere, Atmos. Chem. Phys., 9, 4363-4385, doi:10.5194/acp-9-4363-2009, 2009.

Froyd, K. D., Murphy, D. M., Lawson, P., Baumgardner, D., and Herman, R. L.: Aerosols that form subvisible cirrus at the tropical tropopause, Atmos. Chem. Phys., 10, 209-218, doi:10.5194/acp-10-209-2010, 2010.

Gettelman, A., Birner, T., Eyring, V., Akiyoshi, H., Bekki, S., Brühl, C., Dameris, M., Kinnison, D. E., Lefevre, F., Lott, F., Mancini, E., Pitari, G., Plummer, D. A., Rozanov, E., Shi- 
bata, K., Stenke, A., Struthers, H., and Tian, W.: The Tropical Tropopause Layer 1960-2100, Atmos. Chem. Phys., 9, 16211637, doi:10.5194/acp-9-1621-2009, 2009.

Hamill, P. and Fiocco, G.: Nitric Acid Aerosols at the Tropical Tropopause, Geophys. Res. Lett., 15, 1189-1192, 1988.

Heintzenberg, J., Hermann, M., and Theiss, D.: Out of Africa: High aerosol concentrations in the upper troposphere over Africa, Atmos. Chem. Phys., 3, 1191-1198, doi:10.5194/acp-3-1191-2003, 2003.

Hervig, M. and McHugh, M.: Tropical nitric clouds, Geophys. Res. Lett., 29, 1125, doi:10.1029/2001GL014271, 2002.

Hoffman, D. J.: Increase in the stratospheric background sulphuric acid aerosol mass in the past 10 years, Science, 248, 996-998, 1990.

Homan, C. D., Volk, C. M., Kuhn, A. C., Werner, A., Baehr, J., Viciani, S., Ulanovski, A., and Ravegnani, F.: Tracer measurements in the tropical tropopause layer during the AMMA/SCOUTO3 aircraft campaign, Atmos. Chem. Phys., 10, 3615-3627, doi:10.5194/acp-10-3615-2010, 2010.

Keim, E. R., Fahey, D. W., Del Negro, L. A., Woodbridge, E. L., Gao, R. S., Wennberg, P. O., and Cohen, R. C.: Observations of large reductions in the NO / NOy ratio near the mid-latitude tropopause and the role of heterogeneous chemistry, Geophys. Res. Lett., 23, 3223-3226, 1996.

Krämer, M., Schiller, C., Afchine, A., Bauer, R., Gensch, I., Mangold, A., Schlicht, S., Spelten, N., Sitnikov, N., Borrmann, S., de Reus, M., and Spichtinger, P.: Ice supersaturations and cirrus cloud crystal numbers, Atmos. Chem. Phys., 9, 3505-3522, doi:10.5194/acp-9-3505-2009, 2009.

Krüger, K., Tegtmeier, S., and Rex, M.: Variability of residence time in the Tropical Tropopause Layer during Northern Hemisphere winter, Atmos. Chem. Phys., 9, 6717-6725, doi:10.5194/acp-9-6717-2009, 2009..

Khaykin, S., Pommereau, J.-P., Korshunov, L., Yushkov, V., Nielsen, J., Larsen, N., Christensen, T., Garnier, A., Lukyanov, A., and Williams, E.: Hydration of the lower stratosphere by ice crystal geysers over land convective systems, Atmos. Chem. Phys., 9, 2275-2287, doi:10.5194/acp-9-2275-2009, 2009.

Kottek, M., Grieser, J., Beck, C., Rudolf, B., and Rubel, F.: World Map of the Köppen-Geiger climate classification updated, Meteorologische Zeitschrift, 15, 259-263, 2006.

Kulkarni, G. and Dobbie, S.: Ice nucleation properties of mineral dust particles: determination of onset RHi, IN active fraction, nucleation time-lag, and the effect of active sites on contact angles, Atmos. Chem. Phys., 10, 95-105, doi:10.5194/acp-10-95-2010, 2010.

Law, K. S., Fierli, F., Cairo, F., Schlager, H., Borrmann, S., Streibel, M., Real, E., Kunkel, D., Schiller, C., Ravegnani, F., Ulanovsky, A., d'Amato, F., Viciani, S., and Volk, C. M.: Air mass origins influencing TTL chemical composition over West Africa during 2006 summer monsoon, Atmos. Chem. Phys. Discuss., in press, 2010.

Lee, S.-H., Reeves, J. M., Wilson, J. C., Hunton, D. E., Viggiano, A. A., Miller, T. M., Ballenthin, J. O., and Lait, L. R.: Particle formation by ion induced nucleation in the upper troposphere and lower stratosphere, Science, 301, 1886-1889, 2003.

Lee, S.-H., Wilson, J. C., Baumgardner, D., Herman, R. L., Weinstock, E. M., LaFleur, B. G., Kok, G., Anderson, B., Lawson, P., Baker, B., Strawa, A., Pittman, J. V., Reeves, J. M., and Bui, T. P.: New particle formation observed in the tropical/subtropical cirrus clouds, J. Geophys. Res., 109, 1125, doi:10.1029/2004JD005033, 2004.

Lovejoy, E. R., Curtius, J., and Froyd, K. D.: Atmospheric ioninduced nucleation of sulfuric acid and water, J. Geophys. Res., 109, D08204, doi:10.1029/2003JD004460, 2004.

Luo, B., Peter, T., Fueglistaler, S., Wernli, H., Wirth, M., Kiemle, C., Flentje, H., Yushkov, V. A., Khattatov, V., Rudakov, V., Thomas, A., Borrmann, S., Toci, G., Mazzinghi, P., Beuermann, J., Schiller, C., Cairo, F., Di Donfrancesco, G., Adriani, A., Volk, C. M., Ström, J., Noone, K., Mitev, V., MacKenzie, A. R., Carslaw, K. S., Trautmann, T., Santacesaria, V., and Stefanutti, L.: Dehydration potential of ultrathin clouds at the tropical tropopause, Geophys. Res. Lett., 30, 11-1, 2003a.

Luo, B. P., Peter, Th., Wernli, H., Fueglistaler, S., Wirth, M., Kiemle, C., Flentje, H., Yushkov, V. A., Khattatov, V., Rudakov, V., Thomas, A., Borrmann, S., Toci, G., Mazzinghi, P., Beuermann, J., Schiller, C., Cairo, F., Di Don-Francesco, G., Adriani, A., Volk, C. M., Strom, J., Noone, K., Mitev, V., MacKenzie, R. A., Carslaw, K. S., Trautmann, T., Santacesaria, V., and Stefanutti, L.: Ultrathin Tropical Tropopause Clouds (UTTCs): II. Stabilization mechanisms, Atmos. Chem. Phys., 3, 1093-1100, doi:10.5194/acp-3-1093-2003, 2003b.

Minikin, A., Petzold, A., Ström, J., Krejci, R., Seifert, M., Schlager, H., van Velthoven, P., and Schumann, U.: Aircraft observations of the upper tropospheric fine particle aerosol in the northern and southern hemispheres at mid-latitudes. Geophys. Res. Lett., 30, 1503, doi:10.1029/2002GL016458, 2003.

Mote, P. W., Rosenlof, K. H., Mclntyre, M. E., Carr, E. S., Gille, J. C., Holton, J. R., Kinnersley, J. S., Pumphrey, H. C., Russell III, J. M., and Waters, J. W.: An atmospheric tape recorder: The imprint of tropical tropopause temperatures on stratospheric water vapor, J. Geophys. Res., 101, 3989-4006, 1996.

Murphy, D. M., Thomson, D. S., and Mahoney, M. J.: In-situ measurements of organics, meteoritic material, mercury, and other elements in aerosols at 5 to 19 kilometers, Science, 282, 16641669, 1998.

Murray, B. J., Wilson, T. W., Dobbie, S., Cui, Z., Al-Jumur, S. M. R. K., Möhler, O., Schnaiter, M., Wagner, R., Benz, S., Niemand, M., Saathoff, H., Ebert, V., Wagner, S., and Kärcher, B.: Heterogeneous nucleation of ice particles on glassy aerosols under cirrus conditions, Nature-Geoscience, ngeo817, online 21 March 2010.

Nielsen, J. K., Larsen, N., Cairo, F., Di Donfrancesco, G., Rosen, J. M., Durry, G., Held, G., and Pommereau, J. P.: Solid particles in the tropical lowest stratosphere, Atmos. Chem. Phys., 7, 685695, doi:10.5194/acp-7-685-2007, 2007.

Palazzi, E., Fierli, F., Cairo, F., Cagnazzo, C., Di Donfrancesco, G., Manzini, E., Ravegnani, F., Schiller, C., D'Amato, F., and Volk, C. M.: Diagnostics of the Tropical Tropopause Layer from insitu observations and CCM data, Atmos. Chem. Phys., 9, 93499367, doi:10.5194/acp-9-9349-2009, 2009.

Park, S., Jiménez, R., Daube, B. C., Pfister, L., Conway, T. J., Gottlieb, E. W., Chow, V. Y., Curran, D. J., Matross, D. M., Bright, A., Atlas, E. L., Bui, T. P., Gao, R.-S., Twohy, C. H., and Wofsy, S. C.: The CO2 tracer clock for the Tropical Tropopause Layer, Atmos. Chem. Phys., 7, 3989-4000, doi:10.5194/acp-7-39892007, 2007.

Peter, Th., Luo, B. P., Wirth, M., Kiemle, C., Flentje, H., Yushkov, 
V. A., Khattatov, V., Rudakov, V., Thomas, A., Borrmann, S., Toci, G., Mazzinghi, P., Beuermann, J., Schiller, C., Cairo, F., Di Donfrancesco, G., Adriani, A., Volk, C. M., Strom, J., Noone, K., Mitev, V., MacKenzie, R. A., Carslaw, K. S., Trautmann, T., Santacesaria, V., and Stefanutti, L.: Ultrathin Tropical Tropopause Clouds (UTTCs): I. Cloud morphology and occurrence, Atmos. Chem. Phys., 3, 1083-1091, doi:10.5194/acp-3-1083-2003, 2003.

Plöger, F., Konopka, P., Günther, G., Grooß, J.-U., and Müller, R.: Impact of the vertical velocity scheme on modeling transport in the tropical tropopause layer, J. Geophys. Res., 115, D03301, doi:10.1029/2009JD012023, 2010.

Popp, P. J., Marcy, T. P., Jensen, E. J., Kärcher, B., Fahey, D. W., Gao, R. S., Thompson, T. L., Rosenlof, K. H., Richard, E. C., Herman, R. L., Weinstock, E. M., Smith, J. B., May, R. D., Vmel, H., Wilson, J. C., Heymsfield, A. J., Mahoney, M. J., and Thompson, A. M.: The observation of nitric acid-containing particles in the tropical lower stratosphere, Atmos. Chem. Phys., 6, 601-611, doi:10.5194/acp-6-601-2006, 2006.

Prata, A. J., Carn, S. A., Stohl, A., and Kerkmann, J.: Long range transport and fate of a stratospheric volcanic cloud from Soufrire Hills volcano, Montserrat, Atmos. Chem. Phys., 7, 5093-5103, doi:10.5194/acp-7-5093-2007, 2007.

Randel, W. J., Wu, F., Gettelman, A., Russell III, J. M., Zawodny, J. M., and Oltmans, S. J.: Seasonal variations of water vapor in the lower stratosphere observed in HALOE data, J. Geophys. Res., 106, 14313-14325, 2001.

Randel, W., Wu, F., Oltmans, S., Rosenlof, K., and Nedoluha, G.: Interannual changes of stratospheric water vapor and correlations with tropical tropopause temperatures, J. Atmos. Sci., 61, 21332148, 2004.

Real, E., Orlandi, E., Law, K. S., Fierli, F., Josset, D., Cairo, F., Schlager, H., Borrmann, S., Kunkel, D., Volk, C. M., McQuaid, J. B., Stewart, D. J., Lee, J., Lewis, A. C., Hopkins, J. R., Ravegnani, F., Ulanovski, A., and Liousse, C.: Cross-hemispheric transport of central African biomass burning pollutants: implications for downwind ozone production, Atmos. Chem. Phys., 10, 3027-3046, doi:10.5194/acp-10-3027-2010, 2010.

Rosen, J. M. and Hofmann, D. J.: Balloonborne measurements of condensation nuclei, J. Appl. Met., 16, 56-62, 1977.

Schmale, J., Schneider, J., Jurkat, T., Eichler, H., Rautenhaus, M., Ancellet, G., Voigt, C., Arnold, F., Gerding, M., Mattis, I., and Borrmann, S.: In situ detection of sulfate aerosol layers over Central and Western Europe originating from the volcanic eruptions of Mt. Okmok and Mt. Kasatochi in July and August 2008, J. Geophys. Res., in press, 2010.

Schumann, U.: TROCCINOX - Tropical Convection, Cirrus and Nitrogen Oxides Experiment, Overview, General Assembly 2005 of the European Geosciences Union, Vienna, Austria, 24 April29 April 2005.

Shur, G. H., Sitnikov, N. M., and Drynkov, A. V.: A mesoscale structure of meteorological fields in the tropopause layer and in the lower stratosphere over the Southern tropics (Brazil), Russian Meteorology and Hydrology, 32, 48749, 2007.

Sipilä, M., Berndt, T., Petäjä, T., Brus, D., Vanhanen, J., Stratmann, F., Patokoski, J., Mauldin III, R. L., Hyvärinen, A.-P., Lihavainen, H., and Kulmala, M.: The role of sulfuric acid in atmospheric nucleation, Science, 327, 1243-1246, 2010.

Sokolov, L. and Lepuchov, B.: Protocol of interaction between
Unit for Connection with Scientific Equipment (UCSE) and onboard scientific equipment of Geophysica aircraft (Second edition), Myasishchev Design Bureau (MDB), 1998.

Thomas, A., Borrmann, S., Kiemle, C., Cairo, F., Volk, C. M., Beuermann, J., Lepuchov, B., Santacesaria, V., Matthey, R., Rudakov, V., Yushkov, V., MacKenzie, A. R., and Stefanutti, L.: In-situ measurements of background aerosol and subvisible cirrus in the tropical tropopause region, J. Geophys. Res., 107, 4763, doi:10.1029/2001JD001385, 2002.

Thomason, L. and Peter, T. (Eds.): SPARC Assessment of Stratospheric Aerosol Properties, WCRP-124, WMO/TD-No. 1295, SPARC Report No. 4, Toronto, Canada, (see also: http://www. atmosp.physics.utoronto.ca/SPARC/index.html), 2006.

Vaughan, G., Schiller, C., MacKenzie, A. R., Bower, K., Peter, T., Schlager, H., Harris, N. R. P., and May, P. T.: SCOUTO3/ACTIVE high-altitude aircraft measurements around deep tropical convection, B. Am. Meteorol. Soc., 89, 647-662, 2008.

Voigt, C., Schlager, H., Roiger, A., Stenke, A., de Reus, M., Borrmann, S., Jensen, E., Schiller, C., Konopka, P., and Sitnikov, N.: Detection of reactive nitrogen containing particles in the tropopause region - evidence for a tropical nitric acid trihydrate (NAT) belt, Atmos. Chem. Phys., 8, 7421-7430, doi:10.5194/acp-8-7421-2008, 2008.

Ulanosvky, A. E., Yushkov, V. A., Sitnikov, N. M., and Ravegnani, F.: The FOZAN-II Fast-response Chemiluminescent Airborne Ozone Analyzer, Instrum. Exp. Tech., 44, 249-256, 2001.

Viciani, S., D’Amato, F., Mazzinghi, P., Castagnoli, F., Toci, G., and Werle, P. A.: A cryogenically operated laser diode spectrometer for airborne measurement of stratospheric trace gases, Appl. Phys, B., 90, 581-592, 2008.

Volk, C. M., Riediger, O., Strunk, M., Schmidt, U., Ravegnani, F., Ulanovsky, A., and Rudakov, V.: In-situ tracer measurements in the tropical tropopause region during APE-THESEO, Eur. Comm. Air Pollut. Res., Report 73, 661-664, 2000.

Weigel, R., Hermann, M., Curtius, J., Voigt, C., Walter, S., Bttger, T., Lepukhov, B., Belyaev, G., and Borrmann, S.: Experimental characterization of the COndensation PArticle counting System for high altitude aircraft-borne application, Atmos. Meas. Tech., 2, 243-258, doi:10.5194/amt-2-243-2009, 2009.

Weinzierl, B., Petzold, A., Esselborn, M., Wirth, M., Rasp, K., Kandler, K., Schütz, L., Koepke, P., and Fiebig, M.: Airborne measurements of dust layer properties, particle size distribution and mixing state of Saharan dust during SAMUM 2006, Tellus B, 61, 96-117, 2009.

Wilson J. C., Blackshear, E. D., and Hyun, J. H.: The Function and response of an improved stratospheric condensation nucleus counter, J. Geophys. Res., 88, 6781-6785, 1983.

Wilson, J. C., Lee, S.-H., Reeves, J. M., Brock, C. A., Jonsson, H. H., Lafleur, B. G., Loewenstein, M., Podolske, J., Atlas, E., Boering, K., Toon, G., Fahey, D., Bui, T. P., Diskin, G., and Moore, F.: Steady-state aerosol distributions in the extra-tropical, lower stratosphere and the processes that maintain them, Atmos. Chem. Phys., 8, 6617-6626, doi:10.5194/acp-8-6617-2008, 2008.

WMO: Global Ozone Observing System, Scientific Assessment of Ozone Depletion: 1998, Global Ozone Research and Monitoring Project Report No. 44, Geneva, 1999.

Yushkov, V., Oulanovsky, A., Lechenuk, N., Roudakov, I., Arshinov, K., Tikhonov, F., Stefanutti, L., Ravegnani, F., Bonafe, U., and Georgiadis, T.: A chemiluminescent analyzer for strato- 
spheric measurements of the ozone concentration (FOZAN), J. Atmos. Oceanic Technol., 16, 1345-1350, 1999.
Zimmermann, F., Weinbruch, S., Schütz, L., Hofmann, H., Ebert, M., Kandler, K., and Worringen, A.: Ice nucleation properties of the most abundant mineral dust phases, J. Geophys. Res., 113, D23204, doi:10.1029/2008JD010655, 2008. 